\title{
Ferromanganese nodules and micro-hardgrounds associated with the Cadiz Contourite Channel (NE Atlantic): Palaeoenvironmental records of fluid venting and bottom currents
}

\author{
Francisco Javier González ${ }^{\text {a,* }}$, Luis Somoza ${ }^{\text {a }}$, Ricardo León ${ }^{\text {a }}$, Teresa Medialdea ${ }^{a}$, Trinidad de Torres ${ }^{\text {b }}$, \\ José Eugenio Ortiz ${ }^{b}$, Rosario Lunar ${ }^{c}$, Jesús Martínez-Frías ${ }^{d}$, Raúl Merinero ${ }^{c}$

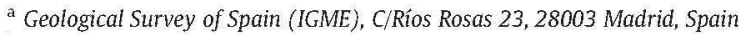 \\ b Laboratorio de Estratigrafia Biomolecular (ETSIM/UPM), C/Ríos Rosas 21, 28003 Madrid, Spain \\ ${ }^{c}$ Departamento de Cristalografia y Mineralogía (UCM), C/José Antonio Novais 2, 28040 Madrid, Spain \\ d Centro de Astrobiología (CSIC/INTA), 29006 Torrejón de Ardoz (Madrid), Spain
}

\begin{abstract}
A B S T R A C T
Ferromanganese nodule fields and hardgrounds have recently been discovered in the Cadiz Contourite Channel in the Gulf of Cadiz ( $850-1000 \mathrm{~m}$ ). This channel is part of a large contourite depositional system generated by the Mediterranean Outflow Water. Ferromanganese deposits linked to contourites are interesting tools for palaeoenviromental studies and show an increasing economic interest as potential mineral resources for base and strategic metals. We present a complete characterisation of these deposits based on submarine photographs and geophysical, petrographic, mineralogical and geochemical data. The genesis and growth of ferromanganese deposits, strongly enriched in Fe vs. Mn (av. 39\% vs. 6\%) in this contourite depositional system result from the combination of hydrogenetic and diagenetic processes. The interaction of the Mediterranean Outflow Water with the continental margin has led to the formation of Late Pleistocene-Holocene ferromanganese mineral deposits, in parallel to the evolution of the contourite depositional system triggered by climatic and tectonic events. The diagenetic growth was fuelled by the anaerobic oxidation of thermogenic hydrocarbons $\left(\delta^{13} \mathrm{C}_{\mathrm{PDB}}=-20\right.$ to $-37 \%$ ) and organic matter within the channel floor sediments, promoting the formation of $\mathrm{Fe}-\mathrm{Mn}$ carbonate nodules. $\mathrm{High}{ }^{87} \mathrm{Sr} /{ }^{86} \mathrm{Sr}$ isotopic values (up to $0.70993 \pm 0.00025$ ) observed in the inner parts of nodules are related to the influence of radiogenic fluids fuelled by deep-seated fluid venting across the fault systems in the diapirs below the Cadiz Contourite Channel. Erosive action of the Mediterranean Outflow Water undercurrent could have exhumed the Fe-Mn carbonate nodules, especially in the glacial periods, when the lower core of the undercurrent was more active in the study area. The growth rate determined by ${ }^{230} \mathrm{Th}_{\text {excess }} /{ }^{232} \mathrm{Th}$ was $113 \pm 11 \mathrm{~mm} / \mathrm{Ma}$, supporting the hypothesis that the growth of the nodules records palaeoenvironmental changes during the last $70 \mathrm{ka}$. Ca-rich layers in the nodules could point to the interaction between the Mediterranean Outflow Water and the North Atlantic Deep Water during the Heinrich events. Siderite-rhodochrosite nodules exposed to the oxidising seabottom waters were replaced by Fe-Mn oxyhydroxides. Slow hydrogenetic growth of goethite from the seawaters is observed in the outermost parts of the exhumed nodules and hardgrounds, which show imprints of the Mediterranean Outflow Water with low ${ }^{87} \mathrm{Sr} /{ }^{86} \mathrm{Sr}$ isotopic values (down to $0.70693 \pm 0.00081$ ). We propose a new genetic and evolutionary model for ferromanganese oxide nodules derived from ferromanganese carbonate nodules formed on continental margins above the carbonate compensation depth and dominated by hydrocarbon seepage structures and strong erosive action of bottom currents. We also compare and discuss the generation of ferromanganese deposits in the Cadiz Contourite Channel with that in other locations and suggest that our model can be applied to ferromanganiferous deposits in other contouritic systems affected by fluid venting.
\end{abstract}

\footnotetext{
* Corresponding author. Tel.: + 34 913495864; fax: + 349133495834.

E-mail address: fj.gonzalez@igme.es (F.J. Gonzălez).
}

\section{Introduction}

Contourite systems have a great potential for containing mineral deposits such as polymetallic/ferromanganese nodules and crusts and energy resources such as oil, gas and gas hydrates (e.g. Kennett, 1982; Stow et al., 2002a; Viana et al., 2007; Rebesco and Camerlenghi, 2008; 
González et al., 2010; Hernández-Molina et al., 2010). Marine ferromanganese deposits are potential mining resources for commercial exploitation of base and strategic metals such as $\mathrm{Mn}, \mathrm{Co}, \mathrm{Cu}, \mathrm{Ni}$ and REEs (e.g. Nicholson et al., 1997; ISA, 2000; Rona, 2008; Hein et al., 2010). Manganese- and ferromanganese-rich horizons are common in contourites (e.g. Faugères et al., 2002a), where they appear as very fine dispersed particles, coatings on terrigenous clasts or bioclasts, fine encrusted horizons or lamina, nodules and micronodules. These horizons have been observed in muddy and biogenic contourites and their genesis is frequently associated with erosive surfaces in relation to high-velocity currents (e.g. Stow et al., 1996; Chester, 2000; Stow et al., 2002b). Manganiferous deposits frequently grow from the cold seabottom waters by only a few millimetres per million years, recording in their structure, texture, mineralogy and geochemistry the oceanic conditions during their growth process. Therefore, they can represent "condensed stratigraphic sequences", which in a few centimetres reflect millions of years of history of the oceans (e.g. Koschinsky et al., 1996; O'Nions et al., 1998; Abouchami et al., 1999; Hein et al., 2000; Hlawatsch et al., 2002; Han et al., 2003; Claude et al., 2005; Stumpf et al., 2010). For this reason, ferromanganese crusts and nodules formed in contourite systems could be an interesting tool for reconstructing the palaeoenvironmental conditions during their formation.

Although there are several references to ferromanganese deposits associated with contourites in the literature (e.g. Massé, 1993; Stow et al., 1996; Faugères et al., 2002a; Viana and Rebesco, 2007), the genetic models for explaining their relations are still poorly understood. In most studies descriptive analyses of ferromanganese deposits are presented but genetic and evolutionary models are only superficially and partially explored. Knowledge of the distribution of these deposits, together with their structural, mineralogical and geochemical characterisation, is necessary in order to understand their formation and evolution. Since their discovery on the Anastasya 2001 cruise, several ferromanganese nodule fields have been studied at the base and flanks of the Guadalquivir Diapiric Ridge (hereafter GDR) in the NE sector of the Gulf of Cadiz (González et al., 2007). This paper describes in detail the ferromanganese nodules and hardgrounds discovered on the middle slope in the Cadiz Contourite Channel (hereafter CCC), a major channel of the Contourite Depositional System of the Gulf of Cadiz generated by the Mediterranean Outflow Water (MOW). This is a very important region for palaeoceanographic/palaeoclimatic reconstructions with implications in global oceanic circulation. The development and evolution of this part of the Gulf of Cadiz margin has been controlled since the Late Messinian by the exchange of water masses through the Strait of Gibraltar, also affected by climatic cycles and tectonic events (e.g. Kenyon and Belderson, 1973; Llave et al., 2006; Voelker et al., 2006; Medialdea et al., 2009; León et al., 2010). We present a complete characterisation of these deposits based on a broad dataset that has led us to propose a genetic and evolutionary model linked to the mud volcanism-diapirism and palaeoceanographic evolution of the $\mathrm{CCC}$, thus increasing knowledge about the interpretation of environmental changes. Finally, the type of ferromanganese nodules defined here could be added to the other types that are known worldwide and help to explain some aspects of this subject that are poorly understood. The model is discussed in relation to other ferromanganese deposits associated with contourite systems.

\section{Oceanographic and geological setting}

The Gulf of Cadiz is connected to the Mediterranean Sea by the Strait of Gibraltar (Fig. 1), the place of interchange between the Atlantic and Mediterranean water masses (Ochoa and Bray, 1991). This location makes the Gulf of Cadiz unique because the interaction between the water masses and the continental margin could have played an important role in the depositional system throughout the most recent geological times (Hernández-Molina et al., 2006). Moreover, the Gulf of Cadiz is a key area for global thermohaline circulation (O'Neill-Barringer and Price, 1999). From the Late Pliocene (2.4 Ma) to the present day, the circulation pattern across the Gibraltar gateway has been characterised by the warm and saline Mediterranean Outflow Waters (MOW) near the bottom, and the inflow of less saline and cool North Atlantic Surface Waters at the surface. The MOW is a strong current that circulates across the slope of the Gulf of Cadiz from the SE to the NW (e.g. Madelain, 1970; Melières, 1974; Loubere, 1987; Ochoa and Bray, 1991; Nelson and Maldonado, 1999; Hernández-Molina et al., 2003; 2006). The MOW divides into two main cores: Mediterranean upper and lower waters, moving across the upper slope $(500-800 \mathrm{~m})$ and the middle slope (800-1200 m), respectively (e.g. Ambar and Howe, 1979a, 1979b; Gardner and Kidd, 1987; Hernández-Molina et al., 2006; Llave et al., 2006; 2007). The North Atlantic Deep Water (NADW) is situated below the MOW (Ochoa and Bray, 1991). The MOW is composed mainly ( $90 \%$ ) of the Levantine Intermediate Water, and to a lesser extent by the Western Mediterranean Deep Water (Bryden and Stommel, 1984). The MOW velocities in different sectors of the Gulf of Cadiz show a high dispersion of values: from $300 \mathrm{~cm} / \mathrm{s}$ in the proximity of the Strait of Gibraltar to $20-80 \mathrm{~cm} / \mathrm{s}$ in the CCC (e.g. Kenyon and Belderson, 1973; Ambar and Howe, 1979a; Nelson et al., 1999; Mulder et al., 2003). These current velocity variations are clearly conditioned by the bottom topography and give rise to sedimentary features such as channels and contourite deposits that have been influenced in the Late Quaternary by climatic and sea level changes, oceanographic conditions and local tectonic events (Hernández-Molina et al., 2006; García et al., 2009).

Since the Zanclean flood that opened the Strait of Gibraltar, a huge contourite depositional system (CDS) has developed on the middle continental slope of the Gulf of Cadiz (e.g. Kenyon and Belderson, 1973; Faugères et al., 1984; Llave et al., 2001; Hernández-Molina et al., 2003; 2006). This CDS is composed of five morphosedimentary sectors: the proximal scour and sand ribbon sector; the overflow sedimentary lobe sector; the channel and ridge sector; and the contourite drift and submarine canyon sector Hernández-Molina et al. (2003). It also has several depositional and erosive features such as contourite channels, furrows and marginal valleys (e.g. Hernández-Molina et al., 2003, 2006; Llave et al., 2006; García et al., 2009). Part of the CDS has developed on the offshore extension of the Betic Chain. The development of the Rifean-Betic orogen is the consequence of the westward drift and collision of the Alboran Domain with the North African and South Iberian margins in the Early to Middle Miocene under the N and NW Africa-Eurasia convergence and the emplacement of huge chaotic masses with a wedge shape (e.g. Maldonado et al., 1999; Medialdea et al., 2004; Platt et al., 2006) (Fig. 1) composed of a chaotic mixture of Triassic, Cretaceous, Palaeogene and Neogene materials (Maldonado et al., 1999). This wedge involves a huge volume of mud and salt diapirism of Triassic salt units and undercompacted Early to Middle Miocene plastic marls (Somoza et al., 2003). The African-Eurasian convergence has promoted fault reactivation and widespread mud-salt diapirism and hydrocarbon-rich fluid venting structures (mud volcanoes, diapiric ridges, carbonate mud mounds, pockmarks and hydrocarbon-derived authigenic carbonates (HDACs)) (e.g. Díaz-del-Río et al., 2003; Somoza et al., 2003; León et al., 2006; Fernández-Puga et al., 2007; González et al., 2009; León et al., 2012; Magalhães et al., 2012).

The study area is situated in the NE sector of the middle slope of the Gulf of Cadiz (Fig. 1), named the channel and ridge sector because of its morphosedimentary characteristics (Llave et al., 2001; HernándezMolina et al., 2003). In this sector, tectonics-and especially diapirismplay a major role in controlling the architecture of the CDS. The sector is located at a depth of 800 to $1600 \mathrm{~m}$ and is dominated by two bathymetric features: diapiric ridges such as the GDR (Fig. 3) and channels such as the Cadiz Contourite Channel (Fig. 3), resulting from the neotectonic activity and the erosive action of bottom currents, respectively. The GDR is a NE-SW elongated diapiric structure $(86 \mathrm{~km}$ 


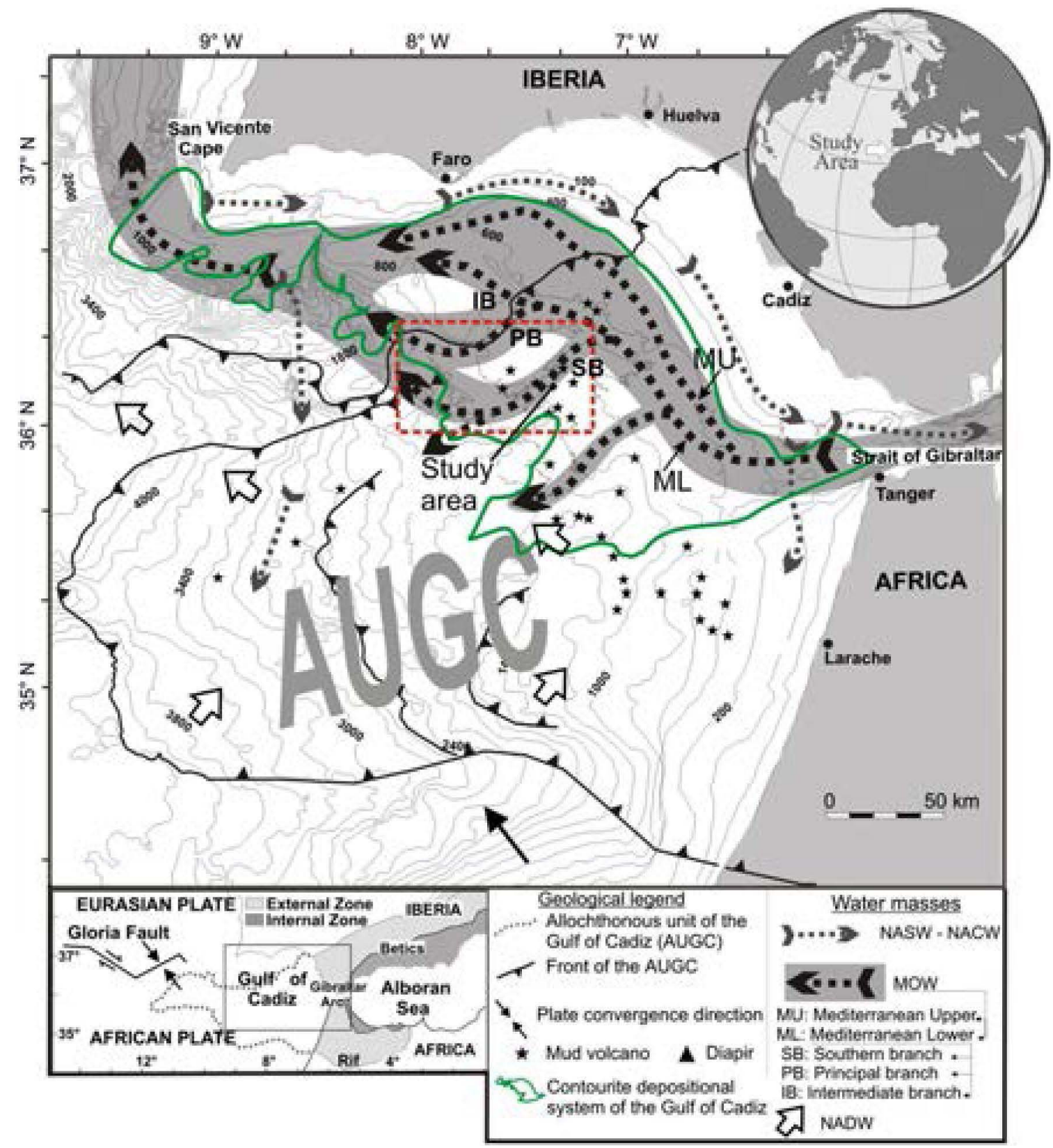

Fig. 1. Geological setting, water mass distribution and circulation and simplified bathymetry of the Gulf of Cadiz. The rectangle marks the situation of the nodule fields in the Guadalquivir Diapiric Ridge area (GDR). Bathymetry is in metres.

Partially modified from Hernández-Molina et al. (2003) and Medialdea et al. (2004).

long) rooted in the Gulf of Cadiz wedge and bound to the north by a set of basement highs such as the Guadalquivir Bank, where Palaeozoic and Mesozoic rocks outcrop (Vegas et al., 2003). This diapiric ridge was generated by the compressional regime and Pliocene-Quaternary sediments appear asymmetrically deformed on its flanks (FernándezPuga et al., 2007). A large variety of hydrocarbon seepage structures (such as carbonate mud mounds, mud volcanoes and HDACs) are visible in multibeam seismic profiles and submarine photographs along this ridge (Somoza et al., 2003; Fernández-Puga et al., 2007; León et al., 2007). At the base of the western flank of the GDR is the CCC running adjacent to the diapiric structure, the largest and most important contourite channel in the area (up to $8 \mathrm{~km}$ wide and $110 \mathrm{~km}$ long). The CCC corresponds with the southern branch, along which the lower core of the MOW circulates with a present-day velocity ranging from 20 to $80 \mathrm{~cm} / \mathrm{s}$ in the study area (e.g. Kenyon and Belderson, 1973; Nelson et al., 1999; García et al., 2009). The GDR forms a topographic high that constricts the MOW circulation pathways, dividing the current into minor branches (Nelson et al., 1993; Hernández-Molina et al., 2003). The lower core of the MOW has acted with different intensity in the CCC during the Late Quaternary. The sedimentary model proposed is different in the cold and the warm stages, the MOW circulation being a principal actor at this time. During cold events, the middle slope was strongly influenced by the MOW action in its lower core, whereas in the warm periods the upper core of the MOW was the most active (Hernández-Molina et al., 2006; Llave et al., 2006). Considering this model, the most erosive action of the MOW in the CCC corresponds with the glacial stages, giving rise to the exhumation of ferromanganese nodules and HDACs at the base and flanks of the GDR. These mineralisations show physical and chemical features that reveal the erosive action of the MOW (González et al., 2007; 2008). The CCC crosses and has eroded fossil contourite deposits composed of mounded, elongate, separated and sheeted drifts (Hernández-Molina 
et al., 2006; Llave et al., 2006). Large erosive incisions up to $200 \mathrm{~m}$ deep have been identified in the CCC (García et al., 2009). The channel floor shows a high backscatter, reflecting the presence of sandy-gravel lags, outcropping diapirs and hard substrates (Nelson et al., 1993; Hernández-Molina et al., 2006). The morphology and near-surface deposits of the middle slope of the Gulf of Cadiz have been controlled by the MoW influence and its interaction with the tectonic features, promoting fluid escape collapses and the generation of specific structures such as blind valleys (León et al., 2010). The S-shape of the CCC in plan view has been interpreted as a result of the interaction between the MOW undercurrent and the tectono-morphostructural features, including neo-tectonic effects on the GDR (Hernández-Molina et al., 2006; García et al., 2009).

\section{Materials and methods}

\subsection{Oceanographic cruise data}

This study is based on a broad dataset obtained in the Gulf of Cadiz (Fig. 2), which was extensively surveyed with swath bathymetry, multi-channel and very high-resolution seismic reflection, underwater cameras, dredging and gravity coring (e.g. Baraza and Ercilla, 1996; Gardner, 2001; Díaz-del-Río et al., 2003; Pinheiro et al., 2003; Somoza et al., 2003; Medialdea et al., 2004; León et al., 2007). Detailed information about the location and the geophysical methods used in this work can be found in the Fig. 2 and the the online Supplementary material respectively.

\subsection{Field site and sample suite}

Twenty dredges (benthic type) and 22 gravity cores were taken along a sector determined from bathymetric, seabed reflectivity and magnetism maps. Samples of ferromanganese nodules, carbonate chimneys and crusts and host sediments (silt-muddy and mudbreccia) were collected from the GDR area (Fig. 2). Nodules were recovered during the Anastasya 2001 cruise aboard the research vessel Cornide de Saavedra using rectangular benthic dredges. Previously collected dredges, bottom photograph surveys taken with a Benthos-372 underwater deep-sea camera and sediment cores indicate the presence of Fe-Mn nodules within the area of high backscatter. The samples recovered comprise 561 ferromanganese nodules with a total weight of $36.6 \mathrm{~kg}$ and several fragments of
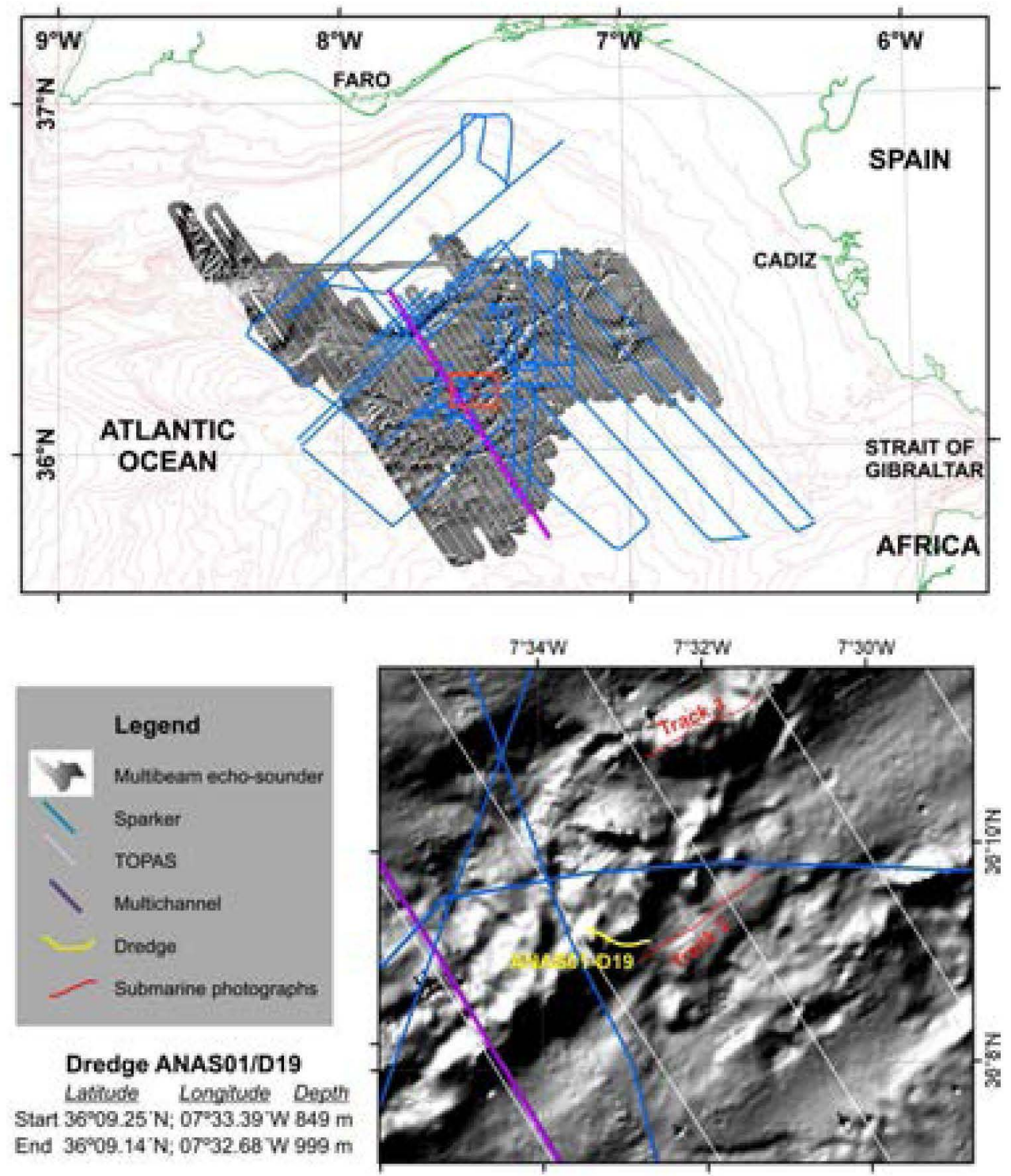

Fig. 2. Study area and datasets studied in this work, including benthic dredges (with coordinates for the sampling site, dredge station ANAS01/D19), submarine photographic tracks, multi and mono-channel (Sparker and TOPAS) reflection seismic data, multibeam echo-sounder mosaic and backscatter imagery. 
HDACs (chimneys and crusts) covered by ferromanganese microhardgrounds. Nodule fields extend in a region along the middle continental slope at an average depth of $900 \mathrm{~m}$. These ferromanganiferous deposits in the Gulf of Cadiz occur in the vicinity of the CCC (on the flanks of mounds) and also on the channel floor.

\subsection{Laboratory analyses}

The 46 selected samples of distinct nodule types and 13 microhardgrounds were studied in the "Centro de Astrobiología" (CAB/ (SIC), the "Centro de Microscopía Electrónica y Citometría" of the Complutense University of Madrid (UCM), the "Laboratorios del Instituto Geológico y Minero de España" (IGME), the "Laboratorio de Isótopos Estables" of the University of Salamanca (USAL), the "Laboratorio de Estratigrafia Biomolecular" of the Polytechnic University of Madrid (UPM) and the GEOMAR Marine Biogeochemistry Laboratory (IFM-GEOMAR). The selection of samples was based on their surface colour, external morphology and size. Selected samples were cut vertically in two halves with respect to their position on the seafloor before macroscopic internal descriptions and physical, X-ray diffraction (XRD), petrographical or chemical analysis. Individual layers of special interest for geochemical and mineralogical determinations were sampled under the microscope with a needle drill.

For weight and maximum diameter measurements and colour and surface texture characterisation, all the nodules collected were used Colour was determined by comparison with the Munsell colour charts (Munsell Color Co., 1980).

The samples were first thoroughly examined by transmitted and reflected light microscopy, and the internal structure was described outlined and photographed. In all, 29 polished sections, 37 thin sections and 46 polished specimens were examined. Bulk mineralogical XRD profiles from $2 \theta=2-60^{\circ}$ in 0.005 steps were obtained in 25 samples using XPERT PRO of PANalytical, $\mathrm{Cu}-\mathrm{K} \alpha$ radiation ( $35 \mathrm{kV}$ and $40 \mathrm{~mA}$ ) with graphite monochromater, High Score software and the ICDD database. Scanning electron microscopy (SEM-EDS) of morphological and 3D textural mineral characteristics was performed on a JEOL JM-6400 instrument.

Thirty-six bulk nodules were measured for major elements (Al, Fe, $\mathrm{Mn}, \mathrm{Ca}, \mathrm{Mg}, \mathrm{Si}, \mathrm{K}$, Ti and P) and trace elements ( $\mathrm{Sc}, \mathrm{V}, \mathrm{Cr}, \mathrm{Co}, \mathrm{Ni}, \mathrm{Cu}, \mathrm{Zn}$, $\mathrm{Pb}, \mathrm{Sr}, \mathrm{Ba}, \mathrm{Br}, \mathrm{Rb}, \mathrm{Zr}, \mathrm{Th}, \mathrm{U}$, As and Mo) by X-ray fluorescence using a MagiX of PANalytical instrument with Rh radiation. Au, $\mathrm{Na}$ and Li were measured using atomic absorption with a VARIAN FS-220 and B by induced coupled plasma atomic emission spectrometry. Accuracy of the data was checked using international standard reference materials, and precision based on duplicate samples was found to be better than $\pm 5 \%$. Loss on ignition was determined by calcination at $950^{\circ} \mathrm{C}$, and $\mathrm{S}$ was measured in ELTRA CS-800 equipment. The bulk REE contents of selected samples were determined by induced coupled plasma mass spectrometry (ICP-MS-TOF) in a RENAISSANCE instrument. The standard reference materials SO-1 (CCMET), GSP-1 (USGS) and BCR-1 (USGS) were used to test the analytical procedure for REE determinations. The accuracy and precision obtained were better than $10 \%$ for all REE. Total organic carbon was estimated for 14 bulk nodules by subtracting the total inorganic carbon obtained by calcination at $550^{\circ} \mathrm{C}$ from the total carbon values measured in ELTRA CS-800 equipment. Multi-elemental spot analyses and mapping of mineral phases and textural features were carried out using electron probe micro analysis (EPMA) with a JEOL JXA-8900M Superprobe operating at 15 to $20 \mathrm{kV}$ and $50 \mathrm{~mA}$ and fitted with wavelength dispersive spectrometers (WDS). Back-scattered electron images were also obtained with this instrument. Standards included pure metals and synthetic and natural minerals, all from international suppliers. Biomarkers were analysed by combined gas chromatography-mass spectrometry. Component identification was based on comparison of the mass spectra and the gas chromatography retention times with published data and reference compounds.
Carbon and oxygen isotopic signatures were measured in carbonate rhomboidal crystals extracted from the nucleus of the nodules. Sulphur isotopes were calculated in pyrites obtained from the $\mathrm{Fe}-\mathrm{Mn}$ layers. In addition, carbon isotopes were measured in bitumens extracted from the ferromanganese nodules. Carbon and oxygen isotope measurements were carried out by fractionated extraction of carbon dioxide (Walters et al., 1972; Al-Aasm et al., 1990 ) with $103 \%$ phosphoric acid at $25^{\circ} \mathrm{C} / 2 \mathrm{~h}$ for calcite, $25^{\circ} \mathrm{C} / 2$ days for dolomite, $25^{\circ} \mathrm{C} / 2$ days for rhodochrosite and $50^{\circ} \mathrm{C} / 9$ days for siderite. Isotopic ratios were measured in a SIRAII VG-Isotech mass spectrometer. For sulphur isotope analyses $\mathrm{SO}_{2}$ was extracted from pyrite by void combustion in presence of $\mathrm{Cu}_{2} \mathrm{O}$ according to the methodologies of Robinson and Kusakabe (1975) and Coleman and Moore (1978), and measured in a SIRAII VG-Isotech mass spectrometer. The reproducibility of the analytical procedure was better than $0.2 \%$ for sulphur, carbon and oxygen. For strontium isotope analysis, equatorial sections of two small sub-spherical nodules were measured for ${ }^{87} \mathrm{Sr} /{ }^{86} \mathrm{Sr}$ using LA-MC-ICP-MS across two continuous profiles from the edge to the centre of the samples according to the internal protocol of the IFM-GEOMAR Laboratory detailed in Fietzke et al. (2008).

The growth rate and age were measured on one nodule by radiometric ${ }^{230} \mathrm{Th}_{\mathrm{xs}} / 232 \mathrm{Th}$ dating by multiple ion counting and inductively coupled plasma mass spectrometry. One continuous depth profile of the entire nodule section was sampled at $0.6-\mathrm{mm}$ intervals using a drilling machine with a numerically controlled drive. A total of 11 samples were collected, yielding between 0.1 and $0.2 \mathrm{mg}$ of material per sample. The treatments and measurements were carried out according to the methodology developed by the IFMGEOMAR Laboratory and detailed in Han et al. (2003) and Fietzke et al. (2005). The growth rate of the micro-hardgrounds was calculated by the Co chronometer method derived by Manheim and LaneBostwick (1988): growth rate $\left(\mathrm{mm} / \mathrm{Ma}^{-1}\right)=0.68 / \mathrm{Co}_{\mathrm{w}}^{1.67}$, where $\mathrm{Co}_{\mathrm{w}}$ is the Co concentration in wt.\% less detrital background concentration of $0.0012 \mathrm{wt} . \%$.

Studies on marine ferromanganese crusts have suggested a relationship between growth rate and chemical composition (e.g., Reyss et al., 1982). The suggestion is based on the hypothesis that the metals in crusts have one source of supply, bottom seawater (hydrogenous), and the amount of Co supplied per unit of time and sea-bottom area is nearly constant in the oceanic water column (Puteanus and Halbach, 1988). Following this assumption, the Co chronometer method is normally used to determine age in Fe-Mn concretions based on the relationship between Co content and growth rate. One limitation of this method is that the equation does not take into account the possible hiatuses during the accretion process. Therefore, the calculated rates represent maximum values and the derived age minimum values (Hein et al., 1990).

\section{Results}

\subsection{Nodule fields: bathymetric, photographic and seismic characterisations}

The study area is characterised by a complex bathymetric seabed configuration in which two significant features stand out: NE-SW topographic highs such as the GDR and adjacent channels such as the CCC. The ferromanganese nodule fields studied are essentially located in the CCC at the base of two carbonate mud mounds named Coruña and Arcos at depths between 850 and $1000 \mathrm{~m}$ (Fig. 3).

The Coruña carbonate mud mound is a NE-SW elongate flat-top feature $230 \mathrm{~m}$ high that has steep slopes $\left(25^{\circ}-30^{\circ}\right)$ and is surrounded by the CCC (Fig. 3). Submarine photographs obtained over the Coruña carbonate mud mound reveal outcrops of the diapiric body, HDACs (chimneys and crusts) and the presence of mud-flow extrusions linked to recent hydrocarbon seepages. The nodule fields appear in submarine photographs at the NE base of this mound in a gap area, 


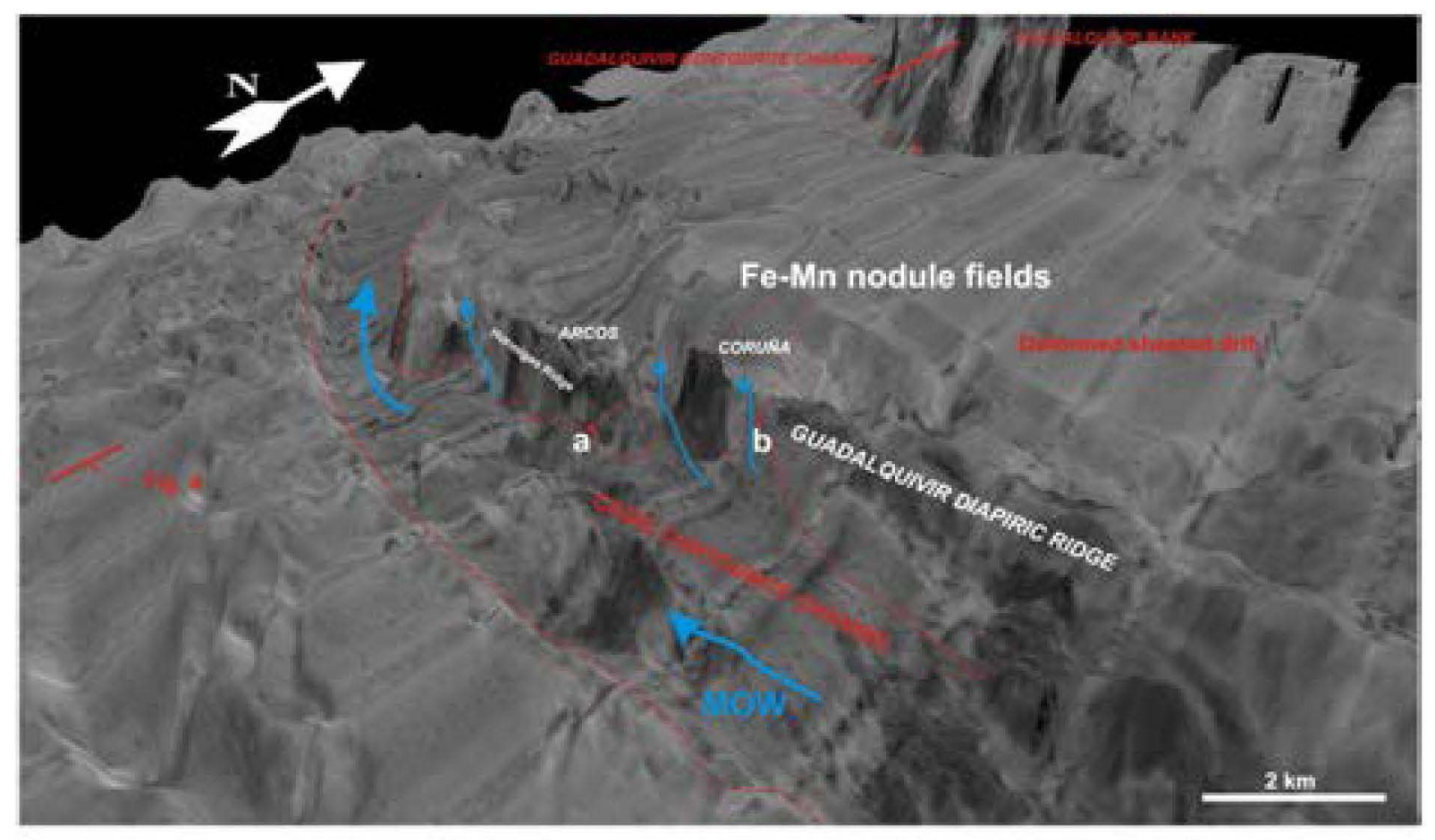

\section{a) TRACK LINE 2}
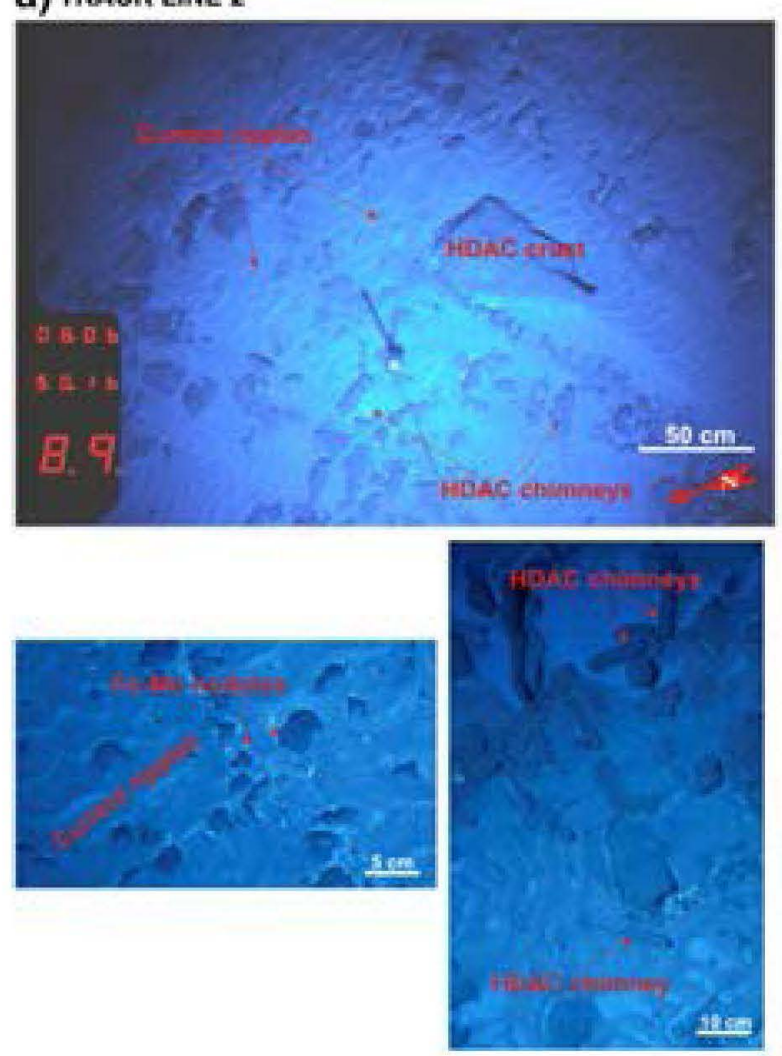

\section{b) TRACK LINE 3}
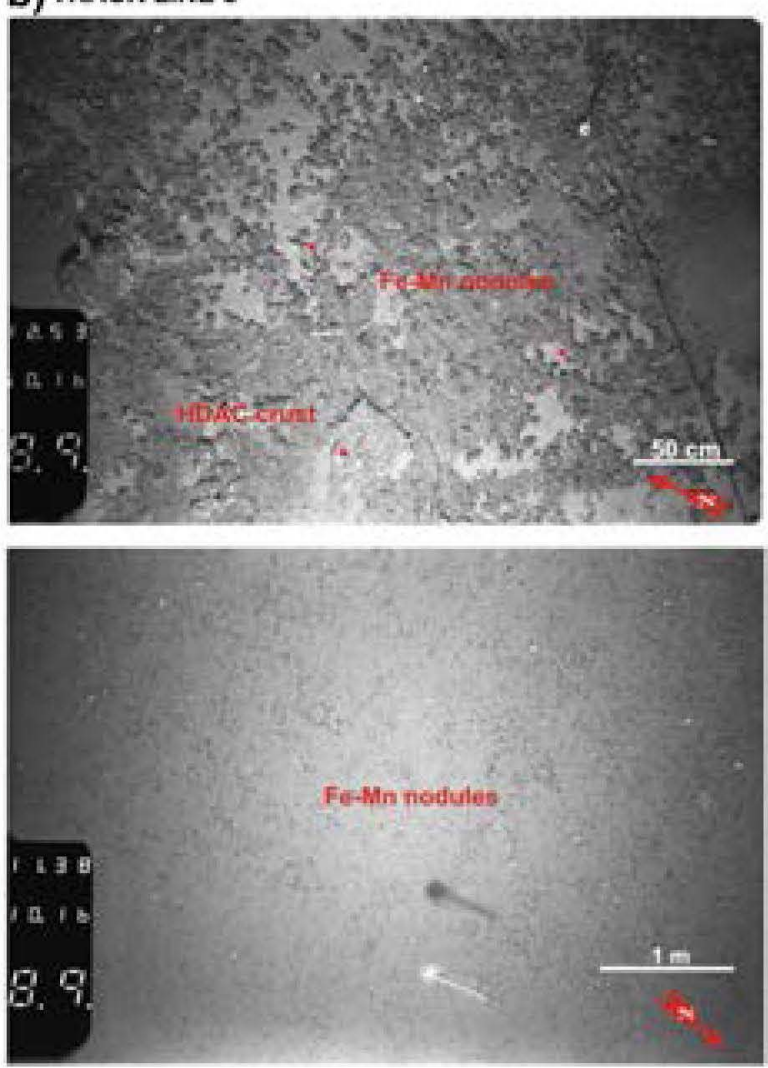

Fig. 3. 3-D multi-beam bathymetric-backscatter images (Simrad EM12-120S), Fledermaus visualisation of the seabed structure map in the study area. Viewing direction is from the east. Black colours indicate high backscatter; grey-white colours indicate low backscatter. Vertical scale enlargement is $2 \times$. For scale and location see Fig. 1 . The underwater images show Fe-Mn nodules and HDACs lying on the seabed (Track Lines 2 and 3). The sedimentary structures show well-developed asymmetrical ripples due to the strong erosive action of the undercurrent and lags of coarse material (Track Line 2); bottom left, detail of these ripples, nodules and carbonate chimneys and crusts stained by oxides.

where secondary flows coming from the southern branch of the MOW that circulates along the CCC cross the GDR (Fig. 3, Track Line 3). Seabed photographs show the nodule fields in a patchy distribution covering sandy sediments. The black nodules have tabular-to-irregular morphologies and sizes ranging from 1 to $10 \mathrm{~cm}$. A high density of nodules covering the seabed is occasionally observed (up to $70 \%$ ), though there are poorly covered areas (3\%$10 \%)$. Sometimes the nodules are accompanying by HDAC-like 
chimneys and pavements of crusts, all of them stained by Fe-Mn oxyhydroxides (Figs. 5 and 6.2).

The Arcos carbonate mud mound is located on the northern side of the NE-SW alignment named the Hormigas Ridge (Fig. 3). It is $200 \mathrm{~m}$ high, is composed of two cone-shaped structures with steep slopes $\left(20^{\circ}-30^{\circ}\right)$, and is surrounded by the CCC. The nodule fields are located at the southern base of the mound, in an area with a gentler slope that is strongly affected by the erosive action of the MOW, giving rise to sandy dune deposits, sandy-gravel lags and current ripples. The submarine photographs show tabular-to-irregular nodules and carbonate chimneys stained by $\mathrm{Fe}-\mathrm{Mn}$ oxyhydroxides of a few centimetres in size covering sandy-gravel sediments frequently associated with current ripples (Fig. 3, Track Line 2). As occurs in the Coruña mound HDAC, outcrops of the diapiric body and mudflows are observed in the submarine photographs of the Arcos mound. In this area, the backscatter mosaic (Fig. 3) shows intermediate values ranging from -33 to $-20 \mathrm{~dB}$. The GDR and the CCC show major changes in the backscatter values in the areas covered by HDACs and ferromanganese nodule fields and mud flows, associated with outcrops of diapirs, carbonate mud mounds and mud volcanoes. These areas are characterised by the highest backscatter values, ranging from -8 to $-15 \mathrm{~dB}$ (Fig. 3 ).

In multichannel seismic profiles the diapiric body is seen to strongly deform the sedimentary sequence in the GDR (Fig. 4a). The diapir sometimes outcrops on the seabed, developing on its top mud volcanoes (e.g., Hespérides) and carbonate mud mounds with extrusive episodes (e.g., Coruña). The internal structure of the diapir is characterised by the presence of columnar transparent facies. Various subvertical seismic chimneys are observed crossing the diapir and deeply rooted (Fig. 4b).

In high-resolution (TOPAS) and Sparker seismic profiles, the contourite deposits are frequently deformed by buried diapirs and pierced by mud volcanoes, giving rise to a deformed sheeted drift in this area (Fig. 4c). In addition, transparent and reflective seismic facies and seismic chimneys are observed, probably related to the presence of hydrocarbon conduits and authigenic precipitates (HDACs), respectively. Sometimes the intergrowth between mudflows and contouritic and hemipelagic deposits is observed on the flanks of mud volcanoes. Erosional features on the flanks and seafloor of the CCC are usually visible in profiles. The areas covered by ferromanganese nodules and HDACs show prolonged echo without sub-bottom reflectors.

\subsection{Structural and textural features}

The studied nodules show a wide range of sizes, morphologies and weights. The most abundant samples range in size from 2 to $4 \mathrm{~cm}$ and have a tabular-to-irregular shape, though there are nodules up to $20 \mathrm{~cm}$ in diameter with an ellipsoidal, spherical, cylindrical or discoidal shape (Fig. 5). The external colour of these ferromanganese nodules ranges from yellow-orange to black, red-brown being the most usual colour. Occasionally, nodules with bright black surfaces are observed. The surface texture is rough to smooth (Fig. 6.1 a and d) and sporadically the presence of burrow-like structures and "alligator skin texture" is visible in large tabular nodules. Encrusting organisms partly covering the nodules (cold water corals, sponges, bryozoans, worms, etc.) are often observed.

Internally, the nodules have three different structural elements: nuclei, layers and discontinuities. The nucleus was not distinguished in all the nodules analysed. Generally, in small samples $(0-2 \mathrm{~cm}$ and sub-spherical), the nucleus is rarely observed and its position is inferred by the concentric pattern of layers (Figs. 5 and 6). In large nodules (up to $20 \mathrm{~cm}$ and tabular-to-irregular in shape), the presence of one or various nuclei forming polynucleated nodules is sometimes observed. There are also samples composed of the accretion of various nodules (polynodules). When the nuclei are visible, they are up to $4.5 \mathrm{~cm}$ in size and frequently beige in colour. Irregular edges impregnated by Fe-Mn oxides were observed in the analysed nuclei (Figs. 5e and 6.1d).

The layers show four textural features: massive, laminated, mottled-to-dendritic and detrital (Fig. 5). They form concentric patterns in small sub-spherical nodules and complex arrangements of laminas in large tabular-to-irregular samples. The layers show dark colours or even opaque colours between yellow and black. The growth of the nodules can be reflected by a well-expressed micrometric to millimetric concentric fabric, especially in small samples, which frequently show a succession of black layers (in which Mn oxides predominate) and yellow or brown layers (in which Fe oxides predominate).

The discontinuities are defined as elements of alteration in the normal arrangement of layers in the ferromanganese nodules studied (Fig. 5). Five types of discontinuity were distinguished: fracture discontinuities (open or filled by mineral precipitates), growth discontinuities (marked by erosional features), burrowing discontinuities, fluidification discontinuities (probably related to fluid migration) and oxidation discontinuities (orange to yellow in colour and affecting 2 to $5 \mathrm{~mm}$ of outer layers).

Ferromanganese encrustations extensively cover surfaces on which HDAC chimneys and pavements have been exhumed by the bottom currents (Fig. 5a). These hardgrounds show a colour ranging from yellow-orange to bright red-brown. Their surface texture is rough with abundant bore-holes (Fig. 6.2a) and encrusting fauna (cold water corals, sponges, bryozoa and worms). Debris of coldwater corals also appear to be covered by thin laminar Fe-( $\mathrm{Mn})$ oxyhydroxides (Fig. 6.2b). Internally, the hardgrounds have a thickness of up to $0.2 \mathrm{~mm}$ and a dense, layered structure; we define them as ferromanganese micro-hardgrounds (Fig. 6.2c).

\subsection{Petrography and mineralogy}

The ferromanganese nodules studied in this paper show a wide range of micro-textural and mineralogical features in their nuclei, layers and outer edges under the petrographic and electronic microscope. The nucleus is formed by a mudstone-to-sandstone siliciclastic sediment cemented by Fe-Mn carbonates. Frequently the nucleus shows Fe-Mn tints (Fig. 6.1d). The carbonate cements (60\%$90 \%$ in volume) form a micro-sparitic mosaic of rhomboidal subidiomorphic to idiomorphic-zoned crystals (Fig. 6.1f). Framboidal pyrite is usually present, dispersed or forming framboidal aggregations, and bioclasts (foraminifera, ostracoda, gastropods and bivalves) occasionally appear. The XRD analyses show the abundance of siderite, with the $d$ (104) ranging between 2.808 and $2.812 \AA$. These values are slightly higher than the characteristic values for pure siderite $(2.795 \AA)$ and lower than those for pure rhodochrosite $(2.84 \AA)$, suggesting an isomorphic mixture of the end members, $\mathrm{Mn}$-siderite and Fe-rhodochrosite.

The layers are usually formed by a micro-sparitic mosaic of subidiomorphic to idiomorphic zoned crystals $(2-10 \mu \mathrm{m})$ of $\mathrm{Fe}-\mathrm{Mn}$ oxyhydroxides (Fig. 6.1e) forming laminated and massive textures or cementing detrital silicates. These layers show the presence of framboids of pyrite, partial or totally replaced by goethite (Fig. 6.1g), and sometimes carbonate bioclasts (foraminifera, ostracoda, gastropods and bivalves). Occasionally, these bioclasts were partially or totally replaced by pyrite (through early diagenesis) and later partially transformed to goethite. Dendritic textures are common in layers affected by fracture discontinuities. Mottled textures with mottles enriched in goethite or Mn-oxides surrounded by silicates and oxyhydroxides are observed in the inner parts of several nodules. Detrital texture is characteristic of layers rich in siliciclastic minerals (quartz and phyllosilicates), in which relicts of sedimentary lamination are usually observed. Fracture discontinuities appear crosscutting layers and nuclei of nodules. Frequently these 
a
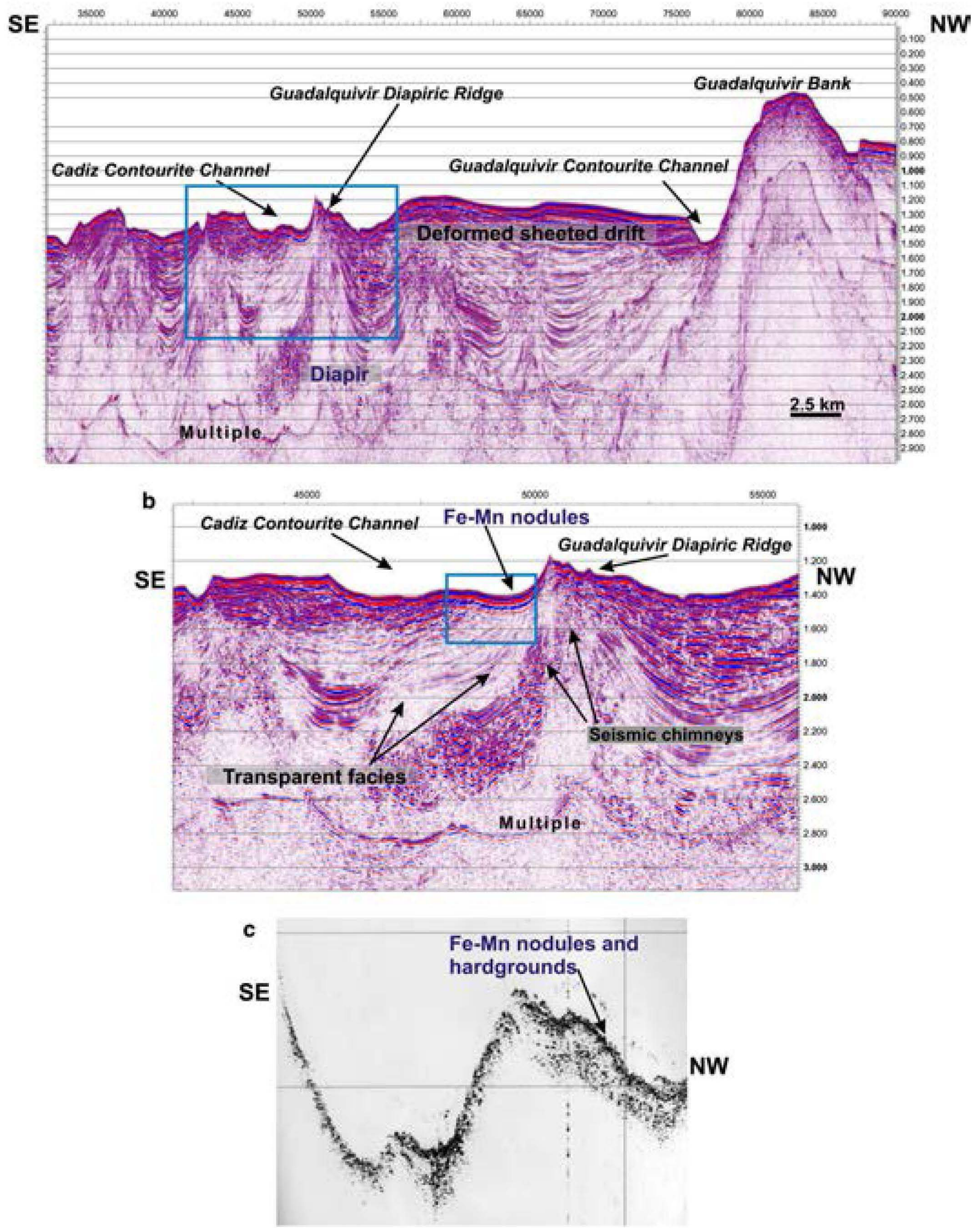

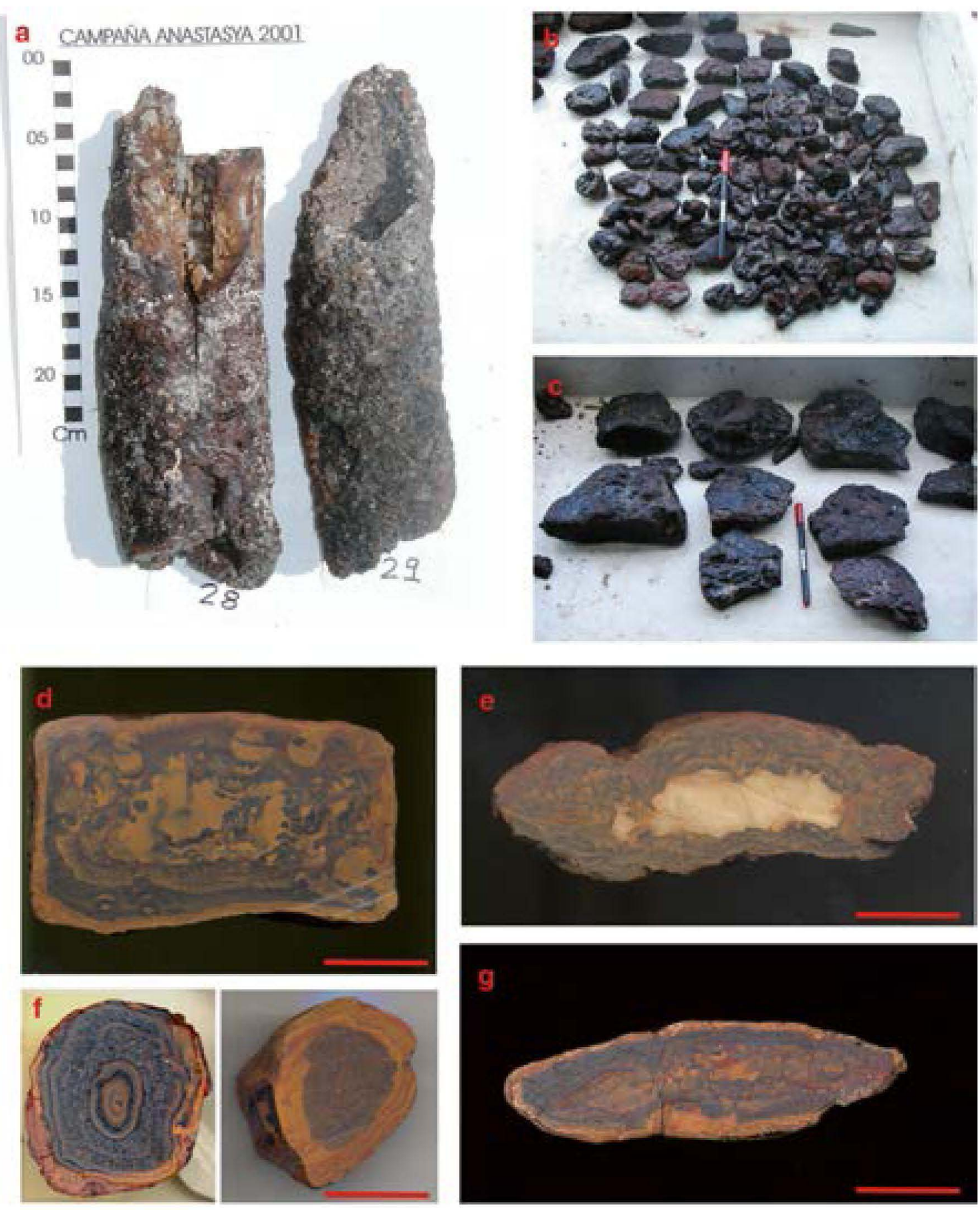

Fig. 5. a) Suite of hydrocarbon-derived carbonate chimneys stained by Fe-Mn micro-hardgrounds. Large tabular-to-irregular nodules recovered in the CCC are shown in images b and $c$. Photographs d, e and g show sections of these nodules. f) Sections of two small sub-spherical to spherical nodules. The outer layers are affected by oxidation front discontinuity (orange in colour), especially visible in images $\mathrm{d}$, $\mathrm{f}$ and $\mathrm{g}$. The scale bars represent $1 \mathrm{~cm}$. (For interpretation of the references to colour in this figure legend, the reader is referred to the web version of this article.

fractures are filled by detrital sediments and/or authigenic precipitates of sparitic calcite and occasionally colloform goethite. In addition, burrowing discontinuities are frequently observed in some nodules. The XRD analyses show the presence of Fe-oxyhydroxides (goethite, lepidocrocite and hematite) as principal minerals in layers, and Mn-oxyhydroxides (pyrolusite, $7 \AA$ A-manganates and $10 \AA \AA$-manganates) in lesser abundance. The silicates are normally also essential minerals, and are especially abundant in layers with detrital textures. The most common silicates are quartz, smectite and illite, but other phyllosilicates, feldspars and zircon are also present. The accessories

Fig. 4. a) and b) NW-SE Tasyo-8 multichannel seismic profile across the channel and ridge sector (modified from Gonzalez et al., 2009). The main diapiric ridges appear affecting the CDS, showing the GDR carbonate mud mounds with an internal chaotic and indistinct seismic reflection pattern and development of "seismic chimneys". A large suite of Fe-Mn nodules was collected on the seafloor of the CCC. c) TOPAS high-resolution seismic profile through the CCC in an area covered by ferromanganese nodules and hardgrounds in HDACs showing prolonged echo without sub-bottom reflectors. For location see Fig. 3. 


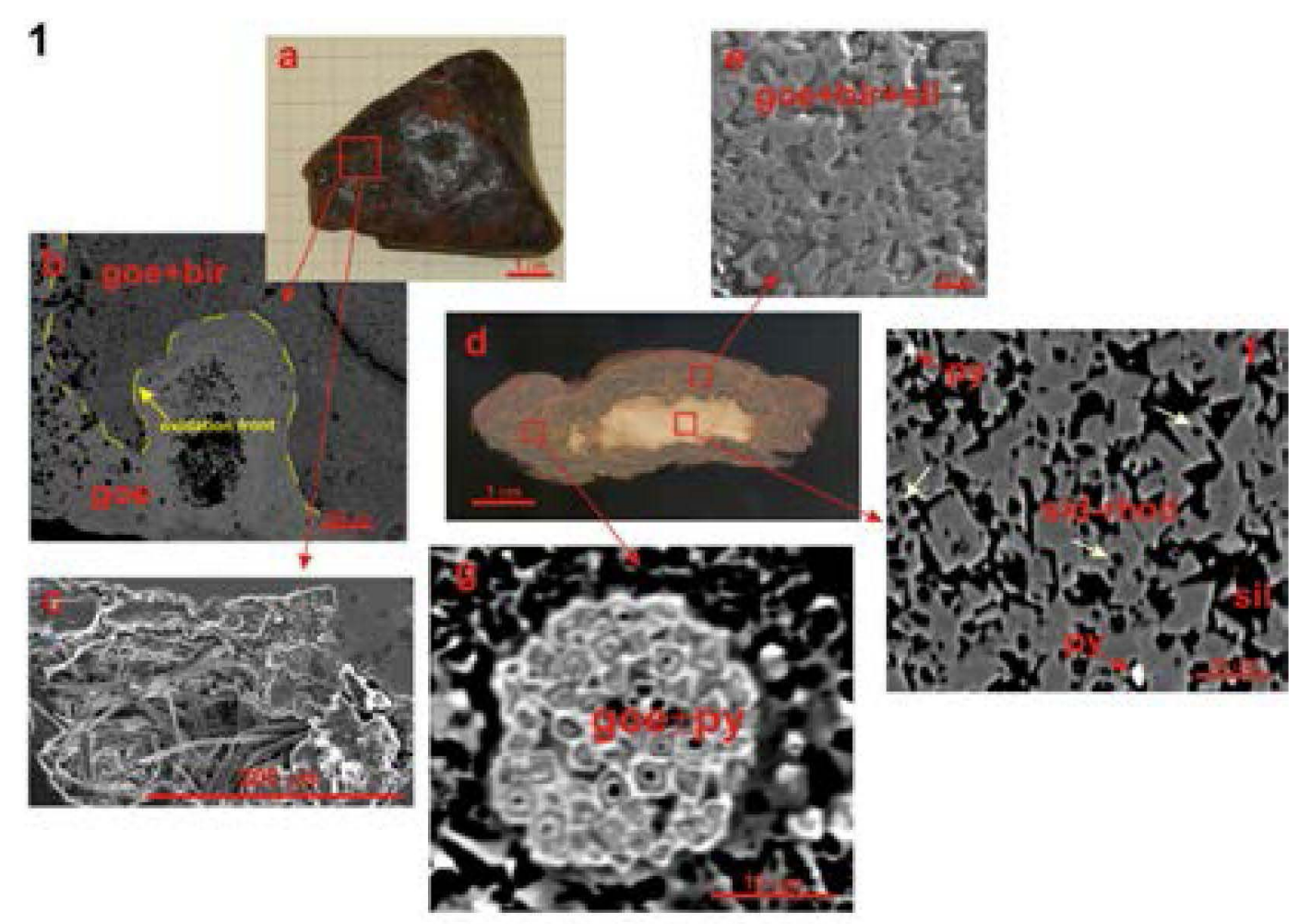

2
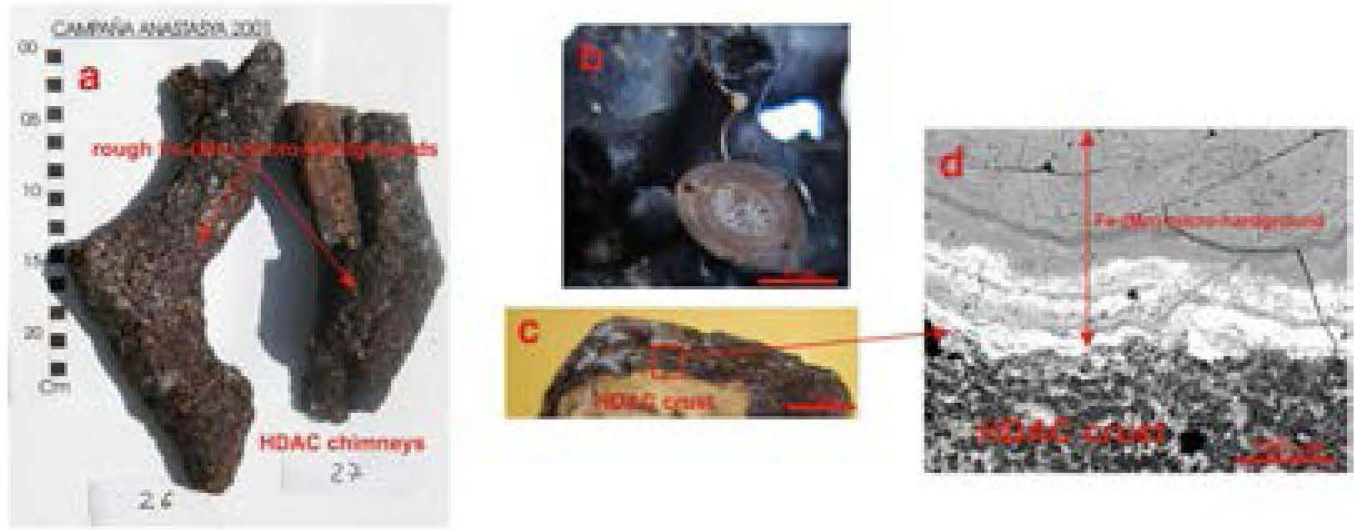

Fig. 6. Sections and details of Fe-Mn nodules and micro-hardgrounds in HDACs, showing typical macroscopic and microscopic internal features (EPMA and SEM photomicrographs). 1a) and b) Smooth surface texture in one nodule enriched in goethite (goe) in the outermost layers. 1c) Filamentous fungi-like texture stained by Fe-Mn oxides on the outer edge of the nodule. 1d) Section of one ferromanganese nodule with Fe-Mn carbonate relict nuclear zone. e) Oxide layer showing goethite-birnessite rhombic crystals (goe + bir) surrounded by Mn oxides (bir) and phyllosilicates (sil).f) Rhomboidal section crystals of Fe-Mn carbonates (sid + rhod) and dispersed pyrite (py). Microbe-like textures in rhomboidal crystals of carbonates with a hole in the centre (white arrows). g) Framboidal texture in biogenic pyrite partially replaced by goethite $2 \mathrm{a}-\mathrm{c}$ ) Surface coatings of ferromanganese micro-hardgrounds in HDACs and coral debris. d) Dense laminated texture of hydrogenetic goethite. (For interpretation of the references to colour in this figure legend, the reader is referred to the web version of this article.)

to occasional minerals in the layers are sulphides (pyrite, marcasite and chalcopyrite), carbonates (calcite, dolomite, kutnahorite) and oxides (ilmenite and rutile).

The outer edges of the ferromanganese nodules show characteristic textural and mineralogical features (Fig. 6.1a and b). Under the microscope a thin succession of colloform micrometric subparallel layers of goethite is observed in the outermost parts of the nodules studied (up to $0.2 \mathrm{~mm}$ ). Unlike in the internal layers and cores of the nodules, mosaics of rhomboidal crystals were rarely observed or were not recognised. In addition, a high open porosity is characteristic of these layers. The presence of Mn-oxyhydroxides is lower than in the inner layers and in the average content of the nodules. The outer layers normally have a discontinuous oxidation front $(2-5 \mathrm{~mm})$, and when the mosaics of rhomboidal crystals appear they show a clear predominance of goethite over other mineral phases (Fig. 6.1b). Carbonate chimneys and crusts recovered in the area show $\mathrm{Fe}-(\mathrm{Mn})$ oxyhydroxides, mainly of goethite, covering their surfaces (micro-hardgrounds of up $0.2 \mathrm{~mm}$ thickness), with textural and mineralogical features similar to the outer edges of the ferromanganese nodules (Figs. 6.2d).

Microbe-like textures were observed by SEM in different parts of the nodules. In the siderite from the nuclei, holes are frequently observed in the centre of the crystals (Fig. 6.1f). Framboidal pyrite crystals with holes and black rims were also detected in cores and layers of ferromanganese nodules (Fig. 6.1g). In addition, rod and fibrous textures developed by Fe-Mn oxides were frequently observed in layers and outer edges of numerous nodules (Fig. 6.1c). 


\subsection{Geochemistry}

The ferromanganese nodules studied show different geochemical characteristics in bulk sample and for each area of analysis: outer edge, layers or nucleus. Major, trace and RE element abundances and ratios are presented in Table 1 . In bulk sample Fe was the most abundant element in the nodules, followed by $\mathrm{Mn}, \mathrm{Si}, \mathrm{Ca}, \mathrm{Mg}$ and $\mathrm{Al}$. These abundances of major elements are in positive correlation with the mineralogical characteristics described above: abundance of FeMn oxyhydroxides, carbonates and silicates. The most abundant trace elements in the nodules studied were Ba, V, Sr, B, As, Ni and Co. In addition to $\mathrm{Fe}$ and $\mathrm{Mn}, \mathrm{Mo}, \mathrm{Co}, \mathrm{Ni}$, As and $\mathrm{V}$ were enriched in the nodules in comparison with the mud-breccia associated sediments (González et al., 2010). On the other hand, $\mathrm{Al}, \mathrm{Si}, \mathrm{K}$ and related elements ( $\mathrm{Rb}, \mathrm{Nb}, \mathrm{Cr}$, Ti or $\mathrm{Zr}$ ) characteristic of silicate minerals were enriched in the mud-breccia host sediments in comparison with the ferromanganese nodules. In relation to average continental crustal abundance (Taylor and McLennan, 1985), several elements were enriched in the nodules from the Gulf of Cadiz by factors of different orders: As (159), Mo (47), Mn (43), B (28), Fe (6), Co (3), V (2) and P (2). $\mathrm{Al}, \mathrm{Si}, \mathrm{K}$ and $\mathrm{Na}$ were depleted elements in comparison with the continental crustal average composition by a factor of between 6 and 11. Shale-normalised REE generally showed a zero to slightly negative

Table 1

Average content and ratios of major ( $w \mathrm{t} \%$ ), traces and REE $(\mu \mathrm{g} / \mathrm{g})$ of the nodules from the Gulf of Cadiz. (a) Average content in oceanic nodules (Data from Baturin, 1988). (b) shallow-water nodules from the Black Sea (data from Sevastyanov and Volkov, 1967 Fomina and Volkov, 1969 and Bogdanov et al., 1995). - : Without data. <d/1: less than detection limit. LOI: Loss on ignition.

\begin{tabular}{|c|c|c|c|c|c|c|}
\hline Element & $\operatorname{Max}$ & Min & Mean & $\begin{array}{l}\text { No. of } \\
\text { samples } \\
\text { analysed }\end{array}$ & $\begin{array}{l}\text { Oceanic } \\
\text { nodules, global } \\
\text { mean (a) }\end{array}$ & $\begin{array}{l}\text { Black Sea } \\
\text { shallow water } \\
\text { nodules (b) }\end{array}$ \\
\hline $\mathrm{Al}$ (wt.\%) & 1.98 & 0.92 & 1.38 & 36 & 2.70 & 1.65 \\
\hline Si & 5.26 & 1.75 & 3.48 & 36 & 7.69 & 5.56 \\
\hline P & 0.30 & 0.05 & 0.19 & 36 & 0.37 & 1.14 \\
\hline K & 0.64 & 0.20 & 0.34 & 36 & 0.73 & - \\
\hline $\mathrm{Na}$ & 0.69 & 0.03 & 0.26 & 36 & 1.97 & - \\
\hline $\mathrm{Ca}$ & 6.57 & 0.62 & 3.15 & 36 & 2.23 & 4.45 \\
\hline $\mathrm{Mg}$ & 2.21 & 1.03 & 1.83 & 36 & 1.57 & 1.04 \\
\hline $\mathrm{Ti}$ & 0.14 & 0.06 & 0.10 & 36 & 0.69 & 0.1 \\
\hline $\mathrm{Fe}$ & 45.06 & 33.06 & 38.58 & 36 & 12.47 & 26.54 \\
\hline $\mathrm{Mn}$ & 9.12 & 3.01 & 6.03 & 36 & 18.60 & 6.79 \\
\hline S & 0.47 & 0.05 & 0.12 & 24 & 0.47 & - \\
\hline LOI & 23.24 & 13.86 & 18.05 & 24 & - & - \\
\hline $\mathrm{Mn} / \mathrm{Fe}$ & 0.25 & 0.07 & 0.16 & 36 & 1.49 & 0.26 \\
\hline $\mathrm{Si} / \mathrm{Al}$ & 3.46 & 1.91 & 2.52 & 36 & 2.85 & 3.37 \\
\hline $\mathrm{Sc}(\mu \mathrm{g} / \mathrm{g})$ & 23 & 13 & 18 & 34 & 50 & - \\
\hline V & 581 & 147 & 339 & 34 & 520 & 186 \\
\hline $\mathrm{Cr}$ & 62 & 21 & 34 & 34 & 70 & 16 \\
\hline $\mathrm{Co}$ & 116 & 60 & 90 & 34 & 2700 & 84 \\
\hline $\mathrm{Ni}$ & 404 & 43 & 108 & 34 & 6600 & 281 \\
\hline $\mathrm{Cu}$ & 62 & 10 & 39 & 34 & 4500 & 37 \\
\hline $\mathrm{Zn}$ & 111 & 32 & 62 & 34 & 1200 & - \\
\hline As & 419 & 23 & 159 & 34 & 140 & 687 \\
\hline $\mathrm{Br}$ & 17 & 3 & 10 & 34 & 21 & - \\
\hline $\mathrm{Rb}$ & 27 & 11 & 17 & 34 & 17 & - \\
\hline $\mathrm{Sr}$ & 601 & 137 & 282 & 34 & 830 & - \\
\hline $\mathrm{Zr}$ & 80 & 38 & 63 & 34 & 560 & 42 \\
\hline $\mathrm{Nb}$ & 7 & 3 & 5 & 34 & 70 & - \\
\hline Mo & 69 & 27 & 47 & 34 & 380 & 18 \\
\hline I & 50 & 4 & 22 & 34 & 400 & - \\
\hline $\mathrm{Ba}$ & 694 & 127 & 352 & 34 & 2300 & - \\
\hline $\mathrm{Pb}$ & 121 & 6 & 18 & 34 & 930 & 16 \\
\hline $\mathrm{Bi}$ & 1 & $<\mathrm{d} / 1(1)$ & $<\mathrm{d} / \mathrm{l}$ & 34 & 7 & - \\
\hline $\mathrm{Au}$ & 47 & $<\mathrm{d} / 1(0.01)$ & $<\mathrm{d} / \mathrm{l}$ & 10 & 0.002 & - \\
\hline $\mathrm{Li}$ & 41 & 7 & 17 & 10 & 80 & - \\
\hline B & 330 & 167 & 278 & 10 & 300 & - \\
\hline Th & 7 & 2 & 4 & 34 & 30 & - \\
\hline U & 9 & 1 & 4 & 34 & 5 & - \\
\hline$\Sigma$ REE & 99 & 55 & 78 & 24 & 1042.5 & 33.2 \\
\hline LREE & 86 & 48 & 68 & 24 & 916 & 31.4 \\
\hline HREE & 14 & 6 & 10 & 24 & 126.5 & 1.8 \\
\hline
\end{tabular}

Ce anomaly $\left(\mathrm{Ce}^{*}=\log 3 \mathrm{Ce}_{\mathrm{n}} / 2 \mathrm{La}_{\mathrm{n}}+\mathrm{Nd}_{\mathrm{n}}\right)$, where $\mathrm{n}$ is shale value (Piper, 1974) ranging between -0.11 and +0.04 , and positive Eu anomalies. In addition, the shale-normalised REE patterns showed a large HREE enrichment and there was a significant LREE/HREE fractionation in all the nodules analysed.

Table 2 shows major and trace element abundances measured by EPMA in the laminated ferromanganese micro-hardgrounds. Iron was the most abundant element related to the predominance of goethite in these layers. $\mathrm{Si}, \mathrm{Al}$ and $\mathrm{Mg}$ appear as accessories in goethite or linked to dispersal detrital silicates. $\mathrm{Co}, \mathrm{As}, \mathrm{V}$ and $\mathrm{P}$ were enriched in these hardgrounds, as well as in the outermost parts of the ferromanganese nodules affected by the oxidation front discontinuity. Similarly, Mn was strongly depleted in the micro-hardgrounds.

The chemical distribution of elements in the nodules is conditioned by the mineralogy and the internal structure. The nuclei were usually enriched in $\mathrm{Ca}$ and $\mathrm{Mg}$ in comparison with the bulk average values. EPMA results revealed that the siderite from the nuclei was consistently $\mathrm{Ca}-\mathrm{Mg}$ - and $\mathrm{Mn}$-rich $\left(\mathrm{CO}_{2}, 40.42 \%\right.$; $\mathrm{FeO}, 41.42 \%$; $\mathrm{MnO}, 7.38 \%$; $\mathrm{MgO}$, $6.75 \% ; \mathrm{CaO}, 4.03 \% ; n=5$ ). In particular, the zoned rhomboidal crystals of siderite were formed by a Fe-rhodochrosite in their inner part and Mn-siderite in their outer part. On a larger scale, interbedded Fe-rich and $\mathrm{Mn}$-rich bands were observed in the cores of ferromanganese nodules. This intercalation of Fe and Mn-rich layers was also observed in the Fe-Mn oxyhydroxides coats surrounding the nucleus (Figs. 7 and 10). Occasionally in the EPMA analysis, thin Ca-rich layers were interbedded, apparently in a cyclic arrangement (Fig. 7). In tabular large nodules the presence of detritus-rich layers was frequently observed within the Fe-Mn coats, which contain a large proportion of terrigenous and biogenic material (bioclasts). Consequently, they had high concentrations of terrigenous ( $\mathrm{Si}, \mathrm{Al}, \mathrm{Ti}, \mathrm{K}, \mathrm{Cr}, \mathrm{Zr}$ and $\mathrm{Y}$ ) and biogenic $(\mathrm{Ca}$ and $\mathrm{Mg}$ ) elements. The outermost layers in the nodules were strongly affected by the oxidation front discontinuity, showing strong enrichment in $\mathrm{Fe}, \mathrm{P}, \mathrm{Zn}, \mathrm{V}, \mathrm{As}$ and $\mathrm{Co}$ in comparison with the other layers and the bulk average contents. On the other hand, Mn was strongly depleted in these layers (Figs. 7 and 10).

In the nodule ANAS01/D19-01 we defined 8 lamina bands (I to VIII) of concentric layers according to their textural and geochemical features. They can be easily identified by the unaided eye and also under the electronic microscope (Fig. 10). The average thickness of lamina bands is about $1 \mathrm{~mm}$. The bands usually start from Fe- and $\mathrm{Mn}$-rich layers and finish in Ca-rich layers strongly depleted in Fe. Different backscatter variations can be recognised within each band, where Fe-rich layers appear bright in reflectivity and Ca-rich layers appear darker (Fig. 10). The outermost layers, affected by the oxidation front discontinuity, show high brightness due to the abundance of trace metals (e.g. Co, As, and V).

Table 2

Average content of major ( $w \mathrm{t} . \%$ ) and traces $(\mu \mathrm{g} / \mathrm{g}$ ) of the ferromanganese microhardgrounds from the Gulf of Cadiz analysed by electron microprobe. $<\mathrm{d} / \mathrm{l}$ : less than detection limit.

\begin{tabular}{lcccl}
\hline Element & Max & \multicolumn{1}{l}{ Min } & Mean & No. of samples analysed \\
\hline $\mathrm{Al}($ wt.\%) & 2.96 & 0.26 & 1.43 & 13 \\
$\mathrm{Si}$ & 4.01 & 0.67 & 1.61 & 13 \\
$\mathrm{P}$ & 1.73 & 0.46 & 1.00 & 13 \\
$\mathrm{Ca}$ & 1.67 & 0.16 & 0.54 & 13 \\
$\mathrm{Mg}$ & 2.27 & 1.05 & 1.59 & 13 \\
$\mathrm{Ti}$ & 0.11 & 0.016 & 0.038 & 13 \\
$\mathrm{Fe}$ & 61.91 & 47.04 & 53.14 & 13 \\
$\mathrm{Mn}$ & 0.16 & 0.024 & 0.064 & 13 \\
$\mathrm{~S}$ & 0.054 & $<\mathrm{d} / 1$ & 0.025 & 13 \\
$\mathrm{~V}(\mu \mathrm{g} / \mathrm{g})$ & 1407 & 367 & 905 & 13 \\
$\mathrm{Co}$ & 881 & 511 & 676 & 13 \\
$\mathrm{Ni}$ & 251 & 165 & 208 & 13 \\
$\mathrm{Zn}$ & 2121 & 297 & 788 & 13 \\
$\mathrm{As}$ & 1943 & 632 & 1125 & 13 \\
$\mathrm{Mo}$ & 407 & 193 & 297 & 13 \\
$\mathrm{~Pb}$ & 919 & 204 & 455 & 13 \\
\hline
\end{tabular}



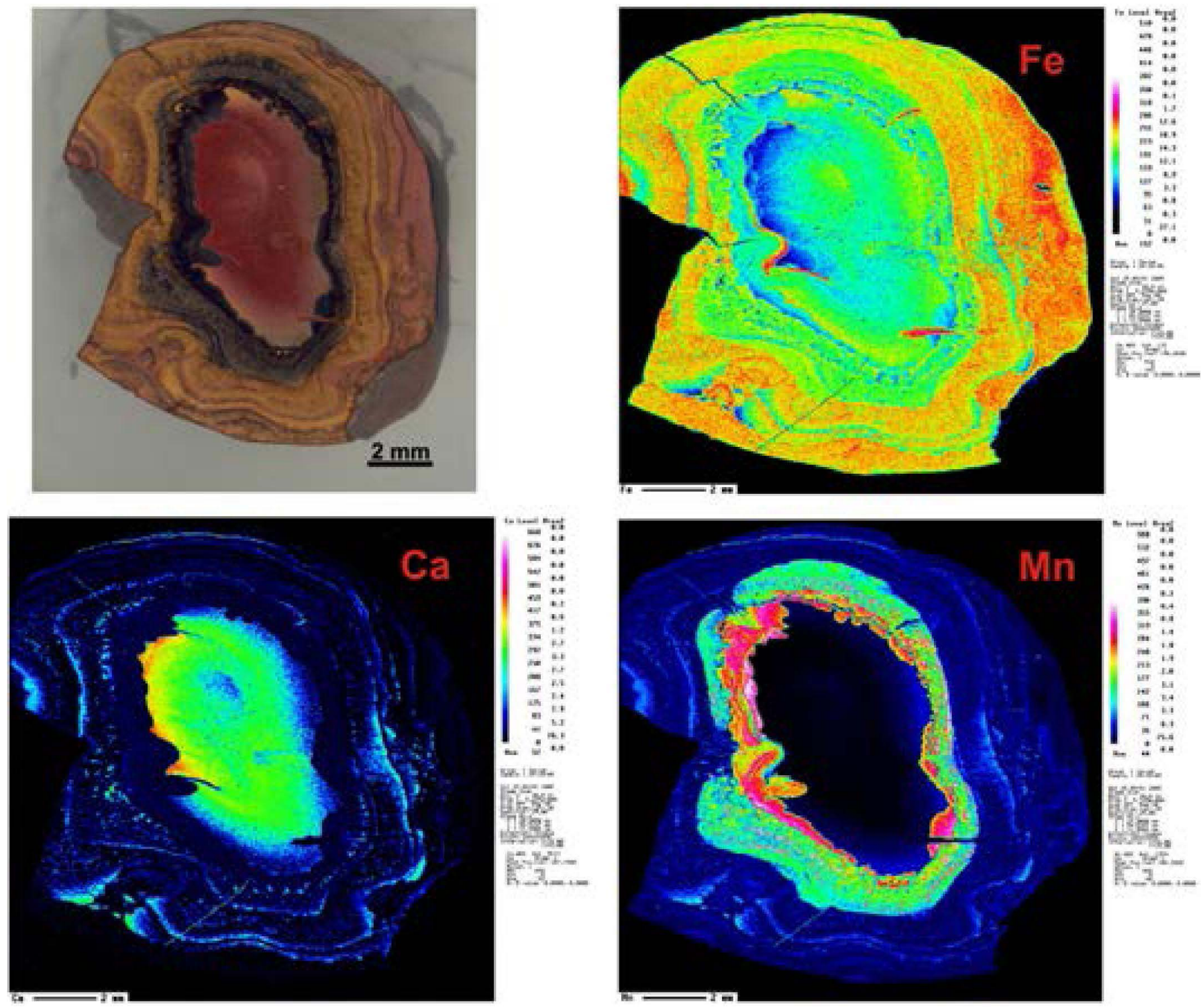

Fig. 7. Iron, manganese and calcium EPMA mapping distribution in the nodule ANAS01/D19-275 (top section). Cool colours indicate low contents; warm colours indicate high contents. We can observe the concentric growth pattern of layers, the Ca enrichment of the nuclear zone and the special Fe enrichment in the outer part of the nodule, affected by oxidation front discontinuity (orange layers). (For interpretation of the references to colour in this figure legend, the reader is referred to the web version of this article.)

The ${ }^{87} \mathrm{Sr} /{ }^{86} \mathrm{Sr}$ isotopic values measured in profiles across two nodules (Fig. 8a) mainly show the typical composition of modern seawater $\left({ }^{87} \mathrm{Sr} /{ }^{86} \mathrm{Sr}=0.709190-0.709200\right)$ (e.g. Palmer and Edmond, 1989; Hodell et al., 1990; Veizer et al., 1999; McArthur et al., 2001; McArthur and Howarth, 2004). Both nodules display high strontium isotope values $(0.70993 \pm 0.00025 ; 0.70992 \pm 0.00023)$ close to the nucleus, and much lower values $(0.70724 \pm 0.00075 ; 0.70693 \pm$ 0.00081 ) in the outer parts affected by the oxidation front (Fig. 8b).

In relation to the organic chemistry, n-alkanes were discovered in the nuclei and layers of the analysed nodules, comprising a unimodal distribution maximising at the $n-C_{18}$ isomer with a major presence of $n-C_{16}$ and $n-C_{20}$ (Fig. 8c). Pristane and phytane and/or crocetane (2, $6,11,15$-tetrametilhexadecane) were detected in all the samples analysed. The carbon preference index (CPI) ranged from 0.66 to 1.15 . Polycyclic aromatic hydrocarbons such as phenanthrene and anthracene were also detected in the nodules. Organic sulphur was detected in the nucleus of one of the two nodules (rich in pyrite). The lipid squalene was present in the nuclei and oxide layers of some samples analysed. The presence of microbe-like geochemical features in carbonates, sulphides and oxides was also detected by SEM-EDS characterisation, showing the abundance of carbon in different textural features (holes, filaments, rims or rods).

In relation to the carbon and oxygen isotopic values for the carbonates, in general the nuclei of the nodules showed low depleted $\delta^{13} \mathrm{C}$ values, ranging from -5.9 to $-10 \%$ and the $\delta^{18} \mathrm{O}_{\mathrm{PDB}}$ ranged from -2.8 to $+3.8 \%$. The lowest values of $\delta^{13} \mathrm{C}$ (as low as $-10.03 \%$ ) corresponded to calcite and dolomite (mean value of $\delta^{13} \mathrm{C}=-7.5 \%$ ). This variability was also observed in their $\delta^{18} \mathrm{O}$ values, the lowest corresponding to calcite $(-2.8 \%$ o to $1.7 \%$ ) and the highest to dolomite (1.1\% to $2 \%$ ). Siderite and rhodochrosite, the most abundant carbonates, showed the highest values for carbon and oxygen isotopes. The values of $\delta^{13} \mathrm{C}$ in siderite ranged from $-5.9 \%$ o to $-7.1 \%$. Rhodochrosite showed values ranging from $-6.9 \%$ to $-8.3 \%$. $\delta^{18} \mathrm{O}$ values ranged from $2.8 \%$ to $3.3 \%$ in siderite and from $2.8 \%$ o to $3.8 \%$ in rhodochrosite. There were no significant differences between the carbon and oxygen isotopic composition of siderites, rhodochrosites, dolomites and calcites from the different nuclei.

The carbon isotopic values for the bitumen extracted from the ferromanganese nodules showed $\delta^{13} \mathrm{C}$ values ranging between $-20 \%$ and $-37 \%$ (vs. PDB) for the $n$-alkane compounds $\left(C_{16}-C_{25}\right)$, 

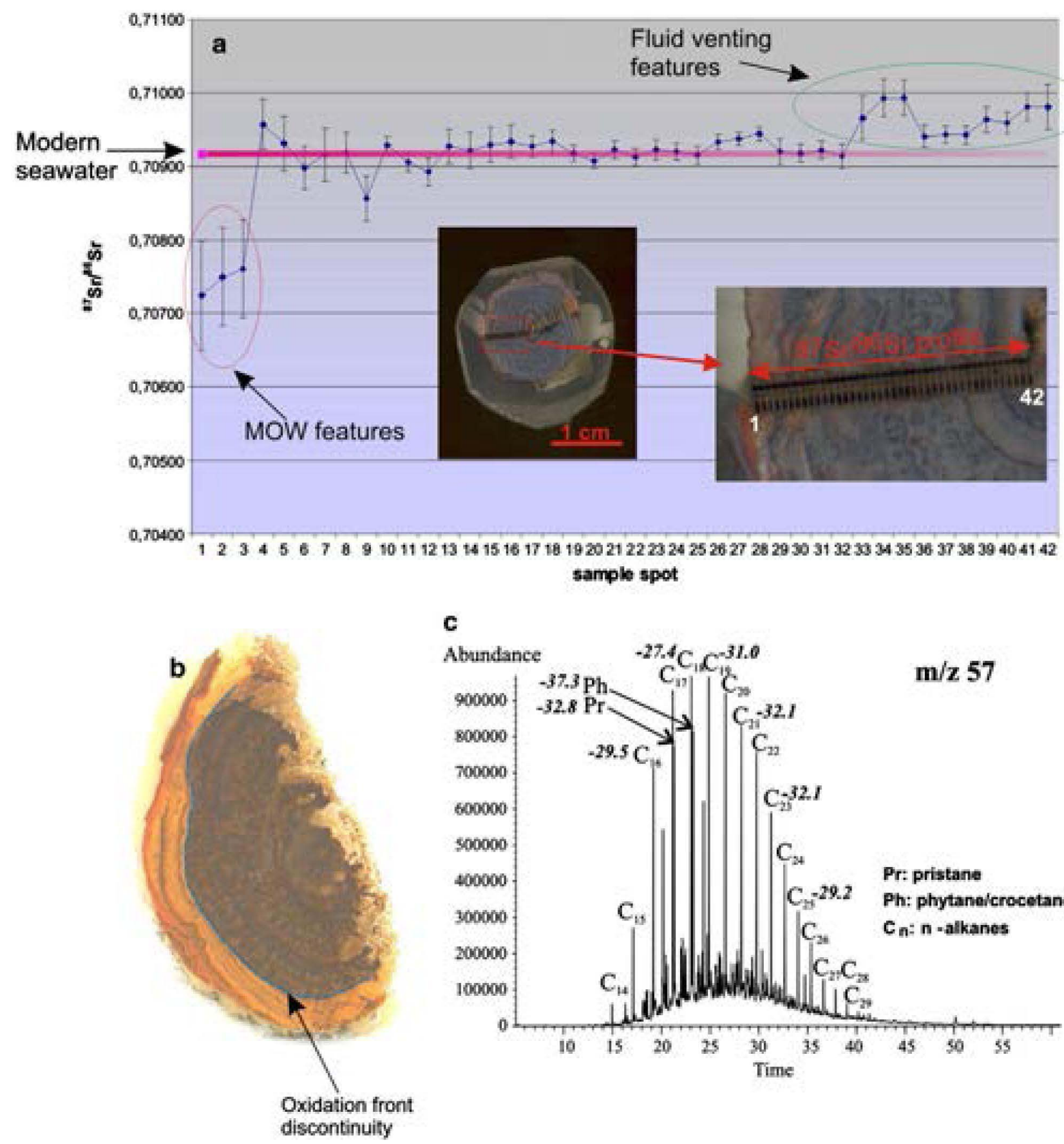

C

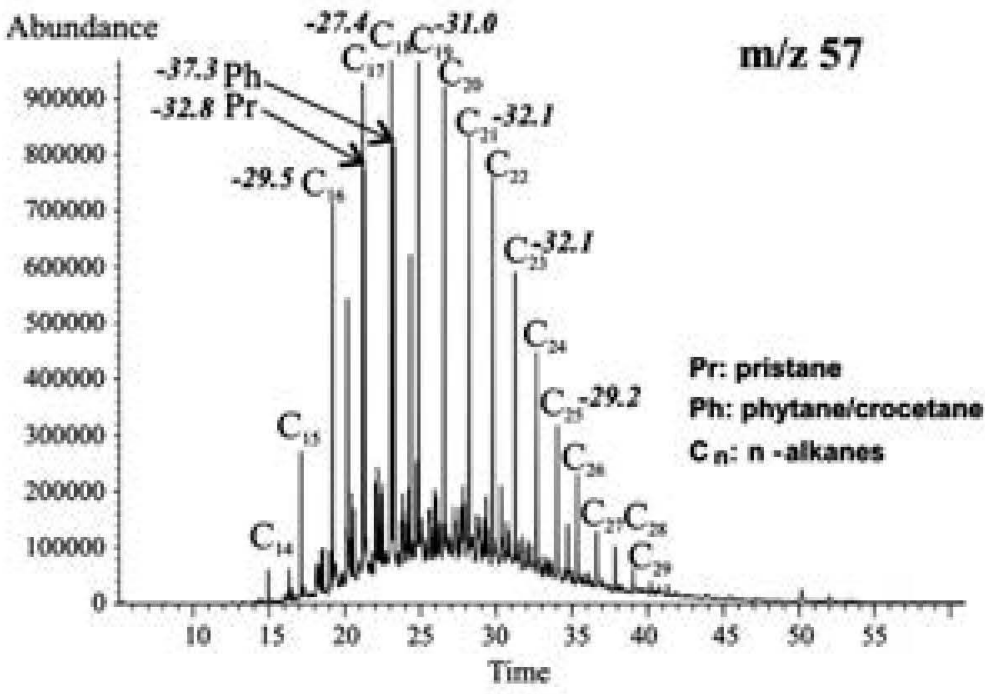

Fig. 8. a) ${ }^{87} \mathrm{Sr} /{ }^{86} \mathrm{Sr}$ LA-MC-ICP-MS analysis across one continuous interval from the edge to the centre of one ferromanganese nodule. The outer edges of the nodule show lower isotopic values in comparison with the oxidation front observed in b). c) GC-MS-IRMS analysis of bitumen content within the inner part of the nodule. Chromatogram and $\delta^{13} \mathrm{C}_{\mathrm{PDB}}$ values of thermogenic hydrocarbon extract shows occurrence of homologous series of normal alkanes ( $\mathrm{n}-\mathrm{Cxx}$ ). Presence of unresolved complex mixture (UCM) and high Pr and Ph contents suggest influence of biodegradation.

pristane and phytane and/or crocetane, indicating their thermogenic origin (Fig. 8c). Framboidal pyrite aggregates from the nodules showed moderate to highly negative ${ }^{34} \mathrm{~S}_{\mathrm{CDT}}$ isotopic values ranging between $+13 \%$ and $-41 \%$.

\subsection{Growth rates and age}

The results obtained for isotope measurements in one nodule are presented in Table 3 . In the nodule studied the ${ }^{230} \mathrm{Th}$ contents ranged from 0.005 to $0.04 \mathrm{pg} / \mathrm{g}$. Th and U showed contents between $1-5$ and $4-10 \mu \mathrm{g} / \mathrm{g}$, respectively. The ${ }^{234} \mathrm{U} /{ }^{238} \mathrm{U}$ ratios ranged between 1.073 and $1.241 \mathrm{dpm} / \mathrm{dpm}$, most of them being far from the typical value for seawater $(1.146 \pm 0.002 \mathrm{dpm} / \mathrm{dpm}) .{ }^{230} \mathrm{Th}$ excess $/{ }^{232} \mathrm{Th}$ ratios decreased as a function of depth. ${ }^{230} \mathrm{Th}_{\mathrm{ex}}$ correction was made for a detrital ${ }^{230} \mathrm{Th} /$ ${ }^{232} \mathrm{Th}$ activity ratio of $0.6 \pm 0.1 \mathrm{dpm} / \mathrm{dpm} .{ }^{230} \mathrm{Th} /{ }^{232} \mathrm{Th}$ results from the ${ }^{230} \mathrm{Th}_{\mathrm{ex}}$ plus the detrital ${ }^{230} \mathrm{Th}$, which is in radioactive equilibrium with its grandmother ${ }^{238} \mathrm{U}$. It is incorporated, for example, in silicate grains and is an additional source of ${ }^{230} \mathrm{Th}$ that has to be corrected; we assumed that we had a typical ${ }^{238} \mathrm{U} /{ }^{232} \mathrm{Th}$ ratio $(\mathrm{dpm} / \mathrm{dpm})$ of about 0.6 (bulk sediments). However, the ${ }^{230} \mathrm{Th}_{\text {excess }} /{ }^{232} \mathrm{Th}$ profile appeared more continuous than the ${ }^{234} \mathrm{U} /{ }^{238} \mathrm{U}$ profile, which does not decrease as a function of depth (Fig. 9). The chemical fluxes into these diagenetic nodules, with precipitation by variable fluxes from the pore water sediment, should be less stable than in hydrogenetic nodules. The ${ }^{238} \mathrm{U} /$ 

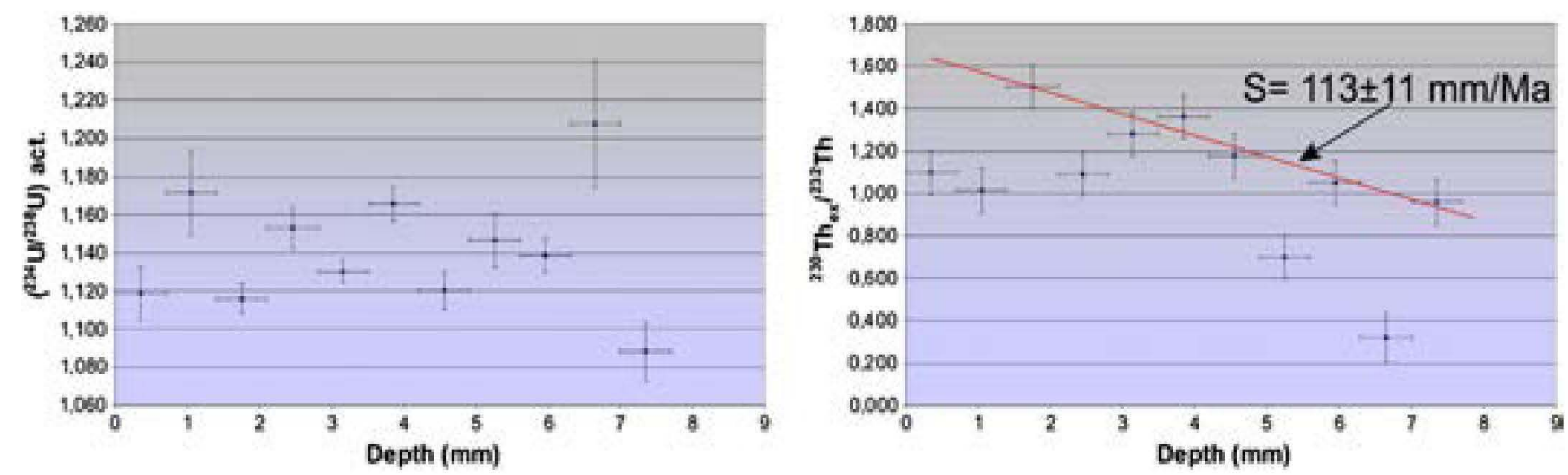

Fig. 9. On the right ${ }^{230} \mathrm{Th}_{\text {excess }}{ }^{232} \mathrm{Th}$ activity profile for the nodule ANAS01/D19-01 (depth: $0-7.5 \mathrm{~mm}$, see Fig. 10). The samples with a high ratio for ${ }^{230} \mathrm{Th}$ excess ${ }^{232} \mathrm{Th}$ and ${ }^{238} \mathrm{U} /{ }^{232} \mathrm{Th} \geq 7$ show the lowest influence of the detrital input and are the most realistic for growth rate calculation. The resulting fit of these data points indicates a growth rate of $113 \pm 11$ mm/Ma. On the left, ${ }^{234} \mathrm{U} /{ }^{238} \mathrm{U}$ profile for the same nodule, showing variable diagenetic chemical fluxes during the growth of the nodule.

${ }^{232}$ Th ratios (Table 3 ) show us how variable the chemical fluxes into the nodule have been. Moreover, the ${ }^{234} \mathrm{U} /{ }^{238} \mathrm{U}$ ratios reflect the diagenetic conditions for nodule accretion, with variable values depending on the redox conditions in the pore water and frequently enriched in ${ }^{234} U$. For this reason, a very variable growth rate is possible in different parts of diagenetic nodules. However, the best approximation is to take one regression line for the average growth rate. The growth rates obtained for the nodule studied were variable, with low and high values ranging between $113 \pm 11$ and $142 \pm 46 \mathrm{~mm} / \mathrm{Ma}^{-1}$ calculated from the logarithmic fit of ${ }^{230} \mathrm{Th}_{\text {excess }} / 232 \mathrm{Th}$. The samples with a high ratio for ${ }^{230} \mathrm{Th}_{\text {excess }} /{ }^{232} \mathrm{Th}$ and ${ }^{238} \mathrm{U} /{ }^{232} \mathrm{Th} \geq 7$ showed the minimum influence of the detrital input and, consequently, their growth rate of $113 \pm 11 \mathrm{~mm} /$ $\mathrm{Ma}^{-1}$ is closer to the reality for this nodule. Hence, assuming that growth and accretion rate is constant, the age of the nodules should be $66.4 \pm 7 \mathrm{ka}$ and the depth resolution of about $0.35 \mathrm{~mm}$ corresponds to $\pm 3 \mathrm{ka}$ (Table 3 ).

The average growth rate of the micro-hardgrounds calculated by the Co chronometer method was $62 \mathrm{~mm} / \mathrm{Ma}$. The age obtained for these thin ferromanganese hardgrounds of $0.2 \mathrm{~mm}$ was approximately $3.2 \mathrm{ka}$, assuming that growth and accretion rate are constant.

\section{Discussion}

In this chapter we present and discuss a combined model for the genesis and evolution of the ferromanganese deposits in the Gulf of Cadiz, where the interaction between the diagenetic and contouritic processes is considered. The ferromanganese nodules and encrustations of the Cadiz Contourite Channel show specific characteristics related to the tectonic and oceanographic setting. The study of the diagenetic features in the nodules could be used to reconstruct the history of pore water fluids during their growth in relation to the widespread mud diapirism and hydrocarbon seeps of the Gulf of Cadiz. Furthermore, the hydrogenetic features observed could be useful to reconstruct the palaeoceanographic conditions during their genesis. How this proposed genetic and evolutionary model could be extrapolated to other worldwide ferromanganese deposits of nodules and crusts formed in such environments is discussed in Section 5.2.

\subsection{Origin and evolution of ferromanganese deposits in the Cadiz Contourite Channel}

The genesis and evolution of the ferromanganese nodules are explained in two stages: (1) the first stage characterised by diagenetic processes below the sediment-water interface under reducing conditions; and (2) the second stage that took place under the influence of the MoW mass, which was responsible for the exhumation of the nodules and has led to major mineral and geochemical transformations in them.

\subsubsection{Stage one: the diagenetic process}

Textural, mineralogical and geochemical data reveal that an early diagenetic process took place in the first stage of growth of the ferromanganese nodules. A characteristic sequence of mineral precipitation can be distinguished from the analysis of the results presented above. The growth of Fe-Mn carbonate nodules started initially under reducing conditions within the fine-grained host sediments (Fig. 11). Authigenic siderite and pyrite, typically formed

Table 3

U-decay series analysis carried out from the high-resolution profile in the equatorial section of the nodule ANAS01/D19-1 (see Fig. 10). Measurements from its outer edge to the nucleus. The excess ${ }^{230} \mathrm{Th}\left({ }^{230} \mathrm{Th}\right.$ ex $)$ was calculated by subtracting the amount of ${ }^{230} \mathrm{Th}$ in secular radioactive equilibrium with the measured ${ }^{238} \mathrm{U}$ concentrations from the originally measured ${ }^{230} \mathrm{Th}$ concentration. ${ }^{230} \mathrm{Th}_{\mathrm{ex}}$ correction was made for a detrital ${ }^{230} \mathrm{Th} /{ }^{232} \mathrm{Th}$ activity ratio of $0.6 \pm 0.1 \mathrm{dpm} / \mathrm{dpm}$. Dpm: decay per minute.

\begin{tabular}{|c|c|c|c|c|c|c|c|c|c|c|}
\hline Sample & Depth & \pm & ${ }^{230} \mathrm{Th} /{ }^{232} \mathrm{Th}$ & \pm & ${ }^{234} \mathrm{U} /{ }^{238} \mathrm{U}$ & \pm & ${ }^{238} \mathrm{U} /{ }^{232} \mathrm{Th}$ & \pm & ${ }^{230} \mathrm{Th}_{\mathrm{ex}} /{ }^{232} \mathrm{Th}$ & \pm \\
\hline$\overline{\text { ANAS01/D19- }}$ & $\mathrm{mm}$ & $\overline{\mathrm{mm}}$ & $\mathrm{dpm} / \mathrm{dpm}$ & $\overline{\mathrm{dpm} / \mathrm{dpm}}$ & $\overline{\mathrm{dpm} / \mathrm{dpm}}$ & $\overline{\mathrm{dpm} / \mathrm{dpm}}$ & $\mathrm{dpm} / \mathrm{dpm}$ & $\overline{\mathrm{dpm} / \mathrm{dpm}}$ & $\mathrm{dpm} / \mathrm{dpm}$ & $\mathrm{dpm} / \mathrm{dpm}$ \\
\hline $1-1$ & 0.35 & 0.35 & 1.700 & 0.025 & 1.119 & 0.014 & 3.702 & 0.013 & 1.100 & 0.103 \\
\hline $1-2$ & 1.05 & 0.35 & 1.615 & 0.033 & 1.172 & 0.022 & 3.094 & 0.013 & 1.015 & 0.105 \\
\hline $1-3$ & 1.75 & 0.35 & 2.102 & 0.024 & 1.116 & 0.008 & 8.493 & 0.023 & 1.502 & 0.103 \\
\hline $1-4$ & 2.45 & 0.35 & 1.691 & 0.031 & 1.153 & 0.011 & 6.324 & 0.020 & 1.091 & 0.105 \\
\hline $1-5$ & 3.15 & 0.35 & 1.880 & 0.021 & 1.130 & 0.006 & 7.710 & 0.021 & 1.280 & 0.102 \\
\hline $1-6$ & 3.85 & 0.35 & 1.962 & 0.032 & 1.166 & 0.009 & 8.160 & 0.024 & 1.362 & 0.105 \\
\hline $1-7$ & 4.55 & 0.35 & 1.777 & 0.032 & 1.120 & 0.010 & 7.270 & 0.023 & 1.177 & 0.105 \\
\hline $1-8$ & 5.25 & 0.35 & 1.300 & 0.027 & 1.147 & 0.014 & 4.324 & 0.017 & 0.700 & 0.104 \\
\hline $1-9$ & 5.95 & 0.35 & 1.651 & 0.028 & 1.139 & 0.009 & 7.439 & 0.022 & 1.051 & 0.104 \\
\hline $1-10$ & 6.65 & 0.35 & 0.921 & 0.053 & 1.208 & 0.033 & 3.406 & 0.021 & 0.321 & 0.113 \\
\hline $1-11$ & 7.35 & 0.35 & 1.559 & 0.041 & 1.088 & 0.015 & 6.964 & 0.027 & 0.959 & 0.108 \\
\hline
\end{tabular}


under reducing conditions, appear in the most internal parts of the nodules. Similarly, some redox-sensitive trace elements such as Mo, $\mathrm{Pb}$ and $\mathrm{As}$ are enriched in the nuclear zones of the nodules. Reducing conditions a few centimetres below the water-sediment interface in the area have been reported by numerous authors (e.g. Díaz-del-Río et al., 2003; Somoza et al., 2003; Stadnitskaia et al., 2006, 2008). In the textural analysis the presence of carbonates (siderite to rhodochrosite) was observed in the nuclei of nodules as micro-sparitic cements formed within fine-grained clastic sediments. These carbonate cements filled a sediment matrix within the host sediment. The presence of fine-grained host sediments within the nodules means that these Fe-Mn carbonate cements must have been formed beneath the sea-bottom surface. The negative $\mathrm{Ce}$ anomalies observed agree with the hypothesis of early-diagenetic processes invoked in other ferromanganese nodules (Glasby et al., 1987; Usui and Someya, 1997). Similarly, burrowing structures (burrowing discontinuities) and relicts of sediment laminations (detritus-rich layers) are frequently observed within the nodules, in agreement with a subsurface origin. Similar textures have been observed in carbonate chimneys and crusts in the area (Díaz-del-Río et al., 2003; Merinero et al., 2008; Magalhães et al., 2012). The host sediments should be rich in hydrocarbons related to the extended mud vulcanism and diapirism of the Gulf of Cadiz (Somoza et al., 2003; Medialdea et al., 2009). In these environments reducing conditions are common and favour carbonate nodule accretion a few centimetres below the sediment-water interface.

Siderite-rhodochrosite nodule formation was possible because of the combination of three conditions that will be analysed: (1) the absence or low concentration of sulphate, (2) the high alkalinity and (3) the high $\mathrm{Fe}^{2+}$ and $\mathrm{Mn}^{2+}$ content in the pore waters. Sideriterhodochrosite precipitates if the sulphate concentration present in the pore water is reduced. It is viable by mediation of sulphate-reducing bacteria (SRB), which reduce $\mathrm{SO}_{4}^{2-}$ from the pore water to $\mathrm{H}_{2} \mathrm{~S}$ and promote the formation of pyrite in presence of $\mathrm{Fe}^{2+}$ (e.g. Berner, 1971; Claypool and Kaplan, 1974; Borowski et al., 1999). The results obtained in the analysed nodules support this hypothesis: the frequent presence of framboidal pyrite in the nodules (e.g. Fig. 6), strongly negative $\delta^{34}$ S and organic sulphur (present in one nucleus rich in pyrite) and other biomarkers (e.g. squalene in various nodules) detected by GC-MS reveal the activity of SRB. Squalene is a lipid present in archaea and commonly symbiotic with SRB living under reducing conditions (Boetius et al., 2000). Archaea have been found in reducing sediments and carbonates from mud volcanoes and mud-carbonate ridges in the study area (e.g. Niemann et al., 2006; Stadnitskaia et al., 2008). The drop in sulphate concentration in the pore waters could be caused by an input of freshwater, which could have resulted from massive gas hydrate dissociation. This assumption is supported by the high oxygen isotopic values obtained in the carbonates from the nodules, up to $+4 \%$, which could indicate dissociation of gas hydrates. It must also be considered that several authors have reported the presence of gas hydrates in deep-water mud volcanoes in the Gulf of Cadiz, and that the limit of the stability zone for hydrates is located in the study area (Gardner, 2001; Mazurenko et al., 2003; Pinheiro et al., 2003; León et al., 2009). In the seismic profiles from the $C C C$ we can observe the presence of buried mud diapir structures and fluid flow from the diapirs to the CCC (Fig. 4), so we can infer fluid venting activity in the CCC. The presence of thermogenic hydrocarbons in ferromanganese nodules from the CCC (Fig. 8c) confirms the migration of hydrocarbons from deep-seated reservoirs to the channel floor. In these conditions gas hydrates could have formed on the seafloor sediments when the area was occupied by the cold NADW and have been dissociated later by the warm action of the Mediterranean waters. A massive dissociation of gas hydrates in the CCC by the action of the MOW could have promoted the formation of collapse structures similar to the blind valleys described by León et al. (2010) in a neighbouring sector of the Gulf of Cadiz.
The high alkalinity of pore waters could also be related to the action of microorganisms in hydrocarbon-rich sediments. Methane and other hydrocarbons contained within the host sediments are oxidised both aerobically and anaerobically by bacterial-mediated processes. The anaerobic oxidation of methane in confined environments such as the pores of fine-grained sediments is mediated by the syntrophic interaction between methanotrophic archaea and SRB (reaction (1)) (Boetius et al., 2000; Hinrichs and Boetius, 2002):

$\mathrm{SO}_{4}^{2-}+\mathrm{CH}_{4} \rightarrow \mathrm{H}_{2} \mathrm{~S}+2 \mathrm{HCO}_{3}^{-}$

In this context dissolved inorganic carbon could have accumulated, increasing the alkalinity sufficiently for the precipitation of carbonates such as $\mathrm{Mg}$-calcite or Ca-dolomite in the presence of divalent metals $\left(\mathrm{M}^{2+}\right.$ ) (reaction (2)) (e.g. Berner, 1981; Borowski et al., 1999; Frankel and Bazylinski, 2003):

$2 \mathrm{HCO}_{3}^{-}+\mathrm{M}^{2+} \rightarrow \mathrm{MCO}_{3}+\mathrm{H}_{2} \mathrm{O}+\mathrm{CO}_{2}$

In addition, the $\mathrm{H}_{2} \mathrm{~S}$ formed is highly reactive and produces iron sulphides such as mackinawite, greigite and pyrite through bacterialinduced mineralisation in the presence of $\mathrm{Fe}^{2+}$ in the pore water in suitable environmental conditions (reaction (3)) (Berner, 1980; Frankel and Bazylinski, 2003):

$\mathrm{H}_{2} \mathrm{~S}+\mathrm{Fe}^{2+} \rightarrow \mathrm{FeS}+2 \mathrm{H}^{+}$

Dissolved inorganic carbon is mainly derived from hydrocarbons, though it can be derived from other sources, as occurred in the nodules studied. Carbon isotopic values measured in the nodular carbonates, as low as $-10 \%$, indicate that several carbon sources may be incorporated within them: methane anaerobic oxidation, fermentation of organic matter, and dissolution of carbonate shells and seawater. Therefore, the authigenic $\mathrm{Fe}-\mathrm{Mn}$ carbonates are formed from dissolved inorganic carbon in the surrounding pore water and reflect the isotopic $\delta^{13} \mathrm{C}$ composition of the dissolved inorganic carbon at the time of carbonate formation. All concretionary carbonate $\delta^{13} \mathrm{C}$ values most likely indicate varying degrees of mixing between ${ }^{13} \mathrm{C}$-depleted bicarbonate produced by methane oxidation and ${ }^{13} \mathrm{C}$-enriched carbon dioxide produced by methanogenesis. Filamentous and framboidal microbe-like textures, isoprenoids, squalene and hopanes could be interpreted as relicts of recent participation of microbes (e.g. archaea and SRB) in the Fe-Mn carbonate mineralisation process. Other organic compounds probably degrade very rapidly, especially in the current oxidising conditions. These textural features and organic compounds have also been defined as signals of biomineralisation in the Gulf of Cadiz (e.g. Díaz-del-Río et al., 2003; Magalhães, 2007; Merinero et al., 2008; Magalhães et al., 2012) and in other hydrocarbon seepage areas (e.g. Peckmann et al., 2001; Peckmann and Thiel, 2004; Konshauser, 2007; Birgel et al., 2008). Precipitation of microbial-induced carbonates or sulphides cannot be clearly assumed from textural observations, but the physico-chemical environmental conditions are suitable for microbial activity, and biomineralisation-microbial communities have been reported in the area (Niemann et al., 2006; Stadnitskaia et al., 2008; Templer et al., 2011). These findings allow us to infer these textural features as indications of microbial-induced mineralisation processes.

Finally, $\mathrm{Fe}^{2+}$ and $\mathrm{Mn}^{2+}$ must be present in high concentrations in the pore water to form $\mathrm{Fe}-\mathrm{Mn}$ carbonates. This means that the supply of $\mathrm{Fe}^{2+}$ must be sufficient to consume the sulphate in the environment (pyrite precipitation) and promote siderite precipitation. We propose that the redox boundary in the sedimentary column is the most feasible area for abundant supply of $\mathrm{Fe}^{2+}$ and $\mathrm{Mn}^{2+}$ (Fig. 11). $\mathrm{Fe}^{3+}$ and $\mathrm{Mn}^{4+}$ reduction processes partial or totally mediated by microorganisms are common in the redox zone (e.g. Hein and Koski, 1987; Nealson and Myers, 1992; Lovley, 1993; Fortin et al., 1997; Tebo et al., 1997; 2004; Kohn et al., 1998; Stein et al., 2001; Frankel and Bazylinski, 2003; Webb et al., 2005; Beal et al., 
2009). The organic matter is oxidised by iron and manganese oxides (reactions (4) and (5)). $\mathrm{Fe}^{3+}$ and $\mathrm{Mn}^{4+}$ are efficient electron acceptors used by dissimilatory reducing microorganisms in direct contact with oxides to reduce them:

$\mathrm{CH}_{2} \mathrm{O}+2 \mathrm{MnO}_{2}+4 \mathrm{H}^{+} \rightarrow 2 \mathrm{Mn}^{2+}+\mathrm{CO}_{2}+3 \mathrm{H}_{2} \mathrm{O}$

$\mathrm{CH}_{2} \mathrm{O}+2 \mathrm{Fe}_{2} \mathrm{O}_{3}+8 \mathrm{H}^{+} \rightarrow 4 \mathrm{Fe}^{2+}+\mathrm{CO}_{2}+5 \mathrm{H}_{2} \mathrm{O}$

thus increasing the levels of pore water $\mathrm{Fe}^{2+}$ and $\mathrm{Mn}^{2+}$, which could precipitate as $\mathrm{Fe}-\mathrm{Mn}$ carbonates (reaction (6)) into high-alkaline reducing zones with the presence of bicarbonate:

$2 \mathrm{HCO}_{3}^{-}+\mathrm{Fe}^{2+} \rightarrow \mathrm{FeCO}_{3}+\mathrm{H}_{2} \mathrm{O}+\mathrm{CO}_{2}$

$2 \mathrm{HCO}_{3}^{-}+\mathrm{Mn}^{2+} \rightarrow \mathrm{MnCO}_{3}+\mathrm{H}_{2} \mathrm{O}+\mathrm{CO}_{2}$

This fact permits the accumulation of Fe-Mn carbonates below the redox boundary. Consequently, the successive redox boundaries must have acted as levels of ferromanganese carbonate nodule formation over time (Fig. 11). The changes in the growth rate during the early diagenesis are related to chemical fluxes within the sediment (Fig. 9). Intercalations between $\mathrm{Fe}$ - and Mn-carbonate laminas must be influenced by different factors: Fe and Mn concentration in the pore waters, sulphate concentration, and $\mathrm{pH}$ or redox potential. The predominance of tabular morphologies observed in the nodules studied could be due to the formation of concretions such as tabular bodies below the redox boundaries. The model of ferromanganese carbonate nodule formation below the redox boundary is the opposite of the models accepted for oxide nodule formation in oxic or suboxic conditions on the abyssal plains. The genesis in these environments is controlled by upwards diffusion of $\mathrm{Fe}^{2+}$ and $\mathrm{Mn}^{2+}$ from the reducing zone to the oxidising zone within the sedimentary column (e.g. von Stackelberg, 2000).

For the supply of Fe and $\mathrm{Mn}$ to the pore water for nodule accretion, there are three principal sources: seawater, sediments and fluid venting. The supply from the seawater must be related to the action of the MOW and its physico-chemical interaction with the sediments of the CCC. The metals were pre-concentrated during long processes of oxidation on the sediment-water interface. Fine-grained sediments, boulders and hard substrates are stained with $\mathrm{Fe}-\mathrm{Mn}$ oxides. If these materials are buried, $\mathrm{Fe}^{3+}$ and $\mathrm{Mn}^{4+}$ can be reduced and finally form $\mathrm{Fe}-\mathrm{Mn}$ carbonate nodules. The detrital or authigenic grain minerals of the sediment (e.g. carbonates, pyrite) could be dissolved, supplying Fe or Mn to the mineralisation process. The other source of metals is the fluid venting activity related to the widespread mud diapirism and mud volcanism occurring in the area. The migration of fluids through these structures includes gas, oil and also water with dissolved ionic components in solution (e.g. Hensen et al., 2007). Enrichments of $\mathrm{Fe}$, As and Mo have been discovered in sediments affected by fluid venting from the Malta Plateau area and are interpreted as geochemical markers of fluids ascending towards the sediment surface (Cangemi et al., 2010). Therefore, fluid venting may contribute to modification of the pore water chemistry. In mud volcanoes of the area radiogenic venting fluids have been reported to appear directly in the pore fluids, with ${ }^{87} \mathrm{Sr} /{ }^{86} \mathrm{Sr}$ isotopic values of up to 0.7099-0.7106 (e.g. Hensen et al., 2007; Scholz et al., 2009). Therefore, high ${ }^{87} \mathrm{Sr} /{ }^{86} \mathrm{Sr}$ isotopic values $(0.70993 \pm 0.00025 ; 0.70992 \pm$ 0.00023 ) observed in the inner parts of nodules (Fig. 8a) could be related to the influence of radiogenic fluids, probably fuelled by deepseated fluid venting across the fault systems in the mud volcanoes and diapirs. The fluids are probably generated by clay mineral dewatering, promoting volcanic activity episodes at the seafloor. Deep thermal maturation of clay minerals has been proposed in the Gulf of Cadiz and other areas affected by mud volcanism to explain the mineralogical nature of mud extrusions (Hensen et al., 2007; Martín-Puertas et al., 2007; Blinova et al., 2011). The diagenetic transformation of smectite into illite takes place at temperatures between 60 and $150{ }^{\circ} \mathrm{C}$, and these diagenetic changes and geochemical rock-fluid interactions contribute to the composition of the ascending fluids, which are highly enriched in B, Sr, Li and other elements (Fe, Mn, etc.) (Hensen et al., 2007; Cangemi et al., 2010; Zheng et al., 2010). Consequently, strong modifications in the chemistry of pore fluids could take place in the surface sediments from these seepage structures and in the precipitation of authigenic minerals (carbonates, sulphides, etc.). In addition, thermogenic hydrocarbons (n-alkanes and phenanthrene) were discovered in the samples analysed (Fig. 8c), in accordance with fluid venting from deep-seated reservoirs towards the sea-bottom through mud diapirs, mud volcanoes and fault systems (González et al., 2009; Medialdea et al., 2009). Hydrocarbons contained in the nodules were also detected in host sediments and carbonate chimneys and crusts in the area.

Considering these arguments, we propose that Fe-Mn carbonate nodules were formed below the redox boundary by successive siderite-rhodochrosite cementation of fine-grained host sediments in concentric layers. The presence of thin Ca-rich coats interlayered with the Fe-Mn layers could correspond to important cyclic changes in the environmental conditions. These changes will be discussed in the next sections in relation to the interaction between the MOW and the NADW in the nodular growth process.

\subsubsection{Stage two: the influence of the Mediterranean Outflow Water and the North Atlantic Deep Water}

The influence of the MOW is visible in submarine photographs, seismic profiles and some textural, mineralogical and geochemical characteristics of the nodules. Submarine photographic tracks show ferromanganese nodules on the sea-bottom, frequently accompanied by HDACs stained by ferromanganese incrustations (Fig. 3). In addition, several signs of high-velocity currents have been observed: ripples of sinuous crests, lags of sandy-gravel sediments, and dunes (Fig. 3 Track Line 2). Moreover, the seismic profiles show the erosive action of the MOW in the CCC (García et al., 2009). All these features bear witness to the strong erosive action of the bottom currents in the area that gives rise to the exhumation of carbonate nodules, chimneys and crusts (HDACs) (González et al., 2007). This exhumation has promoted the mineral and geochemical transformations (oxidation) in the nodules that dominate the second stage of the model (Fig. 11).

During their diagenetic growth, the nodules acquired different characteristics in close relation to the properties of the pore-water fluids. The zone proposed for nodule formation, below the redox boundary, is close to the sediment water interface, so the influence of the oceanic water masses in the pore water composition must be great. The thin laminations of calcite interlayered with Fe-Mn oxide layers in nodules have been interpreted as a result of changes in the pore water chemistry (Fig. 11). These changes could be driven by variations in the characteristics of the MOW and by the interaction between water masses in the area (MOW and NADW). This interpretation is consistent with the growth rates and age obtained by ${ }^{230} \mathrm{Th}_{\text {excess }}{ }^{232} \mathrm{Th}$ dating (Fig. 10). During Heinrich events and Maximum Glacial conditions, the MOW had a significantly higher salinity and density (Zahn et al., 1987; Cacho et al., 2000), generating a deeper and more intensive current and promoting the erosive action and development of coarse contourite deposits in the study area (Llave et al., 2006; García et al., 2009). During the cool stage, the strong erosive action of the MOW supported the exhumation of nodules and variations of the redox boundaries (Fig. 11). The MOW could have been rich in Fe and $\mathrm{Mg}$, especially in the glacial periods, when the lower sea level permitted the wash of continental shelves and sufficient input of fluvial waters with elevated Fe contents (Hamoumi and Chafik, 2006; Kozlova et al., 2007). Consequently, thin encrustations of Fe-rich hydrogenous oxides could be formed, staining nodules and HDAC chimneys and crusts during these periods. On the other hand, at the end of the cool stages, during the Heinrich 

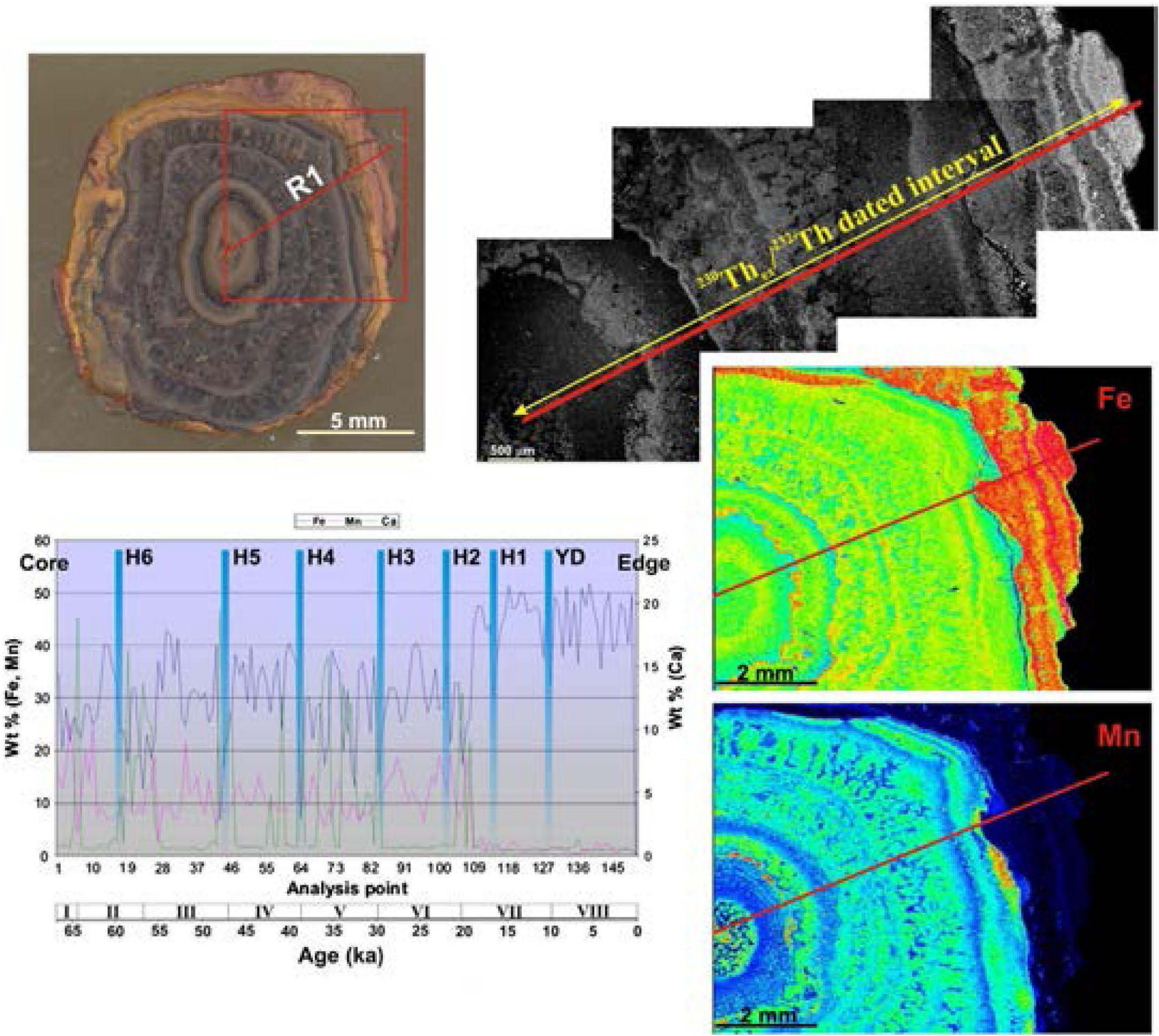

Fig. 10. Top, equatorial section of the nodule ANAS01/D19-01 and backscatter EPMA image with situation of chemical and dating profiles. Below right, iron and manganese EPMA mapping distribution in the nodule. Cool colours indicate low contents; warm colours indicate high contents. Below left, EPMA distribution for Fe, Mn and Ca across the R1 profile every $50 \mu \mathrm{m}$ from the core to the outer edge of the nodule. The time scale is according to ${ }^{230} \mathrm{Th}$ excess $/{ }^{232} \mathrm{Th}$ dating. Iron, manganese and calcium may show a certain cyclicity in their patterns, which may be related to the interaction of the MOW and NADW. Each lamina band defined (I-VIII) corresponds approximately to the time span between Heinrich events. Heinrich events are based on the oxygen isotope stack from the GISP2 and NGRIP Greenland ice cores: Grootes et al. (1993); Meese et al. (1994); Grootes and Stuiver (1997). (For interpretation of the references to colour in this figure legend, the reader is referred to the web version of this article.)

events, the NADW invaded the zone. This water mass is characterised in turn by its high oxygen content, contributing to the oxidising conditions in the pore waters and therefore to the precipitation of calcite. Alternatively, the NADW could enhance deposition of fine sediments in the CCC and burial of nodules at a deeper level within the sedimentary column, favouring calcite-dolomite precipitation under reducing conditions. This phenomenon of burial and exhumation may be related to the exchange between water masses from glacial to interglacial time.

The exhumation process resulting from the MOW action, especially strong during the cool stages, has generated different transformations in the nodules. The Fe-Mn carbonate nodules exhumed were in contact with the sea-bottom oxidising waters. Under these conditions, the carbonates (siderite-rhodochrosite) and pyrite were transformed into Fe-Mn oxyhydroxides (Fig. 11). In addition to the oxidative process of ferromanganese carbonates, $\mathrm{Mn}^{2+}$ and $\mathrm{Fe}^{2+}$ oxidation from surrounding pore water fluids could be also present during the exhumation process. In the presence of low levels of oxygen, soluble $\mathrm{Mn}^{2+}$ and $\mathrm{Fe}^{2+}$ diffuse upwards from reduced sediments to form oxyhydroxides close to the oxic-anoxic interface with the intervention of microbes (e.g. Fortin et al., 1997; Nealson and Stahl, 1997; Tebo et al., 1997; Frankel and Bazylinski, 2003). $\mathrm{Fe}^{2+}$ and $\mathrm{Mn}^{2+}$ oxidation are thermodynamically favoured (reactions (7) and (8)). At neutral $\mathrm{pH}, \mathrm{Mn}^{2+}$ oxidation requires biological intervention:

$\mathrm{Mn}^{2+}+1 / 2 \mathrm{O}_{2}+\mathrm{H}_{2} \mathrm{O} \rightarrow \mathrm{MnO}_{2}+2 \mathrm{H}^{+}$

$\mathrm{Fe}^{2+}$ is rapidly oxidised without involvement of microbes:

$\mathrm{Fe}^{2+}+1 / 2 \mathrm{O}_{2}+2 \mathrm{H}^{+} \rightarrow 2 \mathrm{Fe}^{3+}+\mathrm{H}_{2} \mathrm{O}$ 

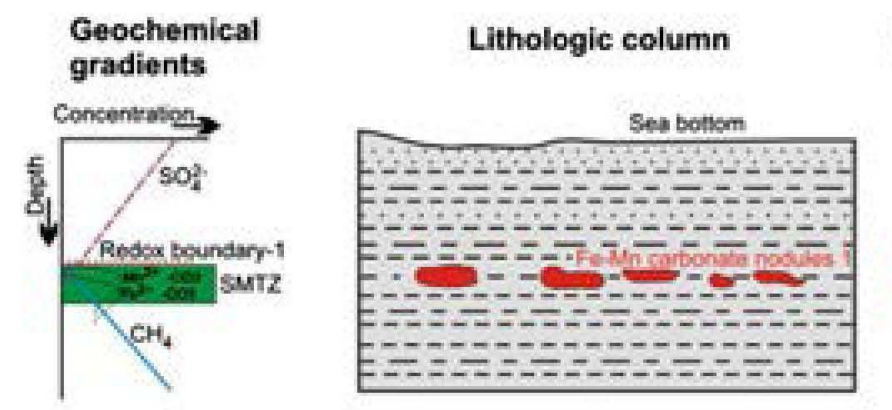

Internal features
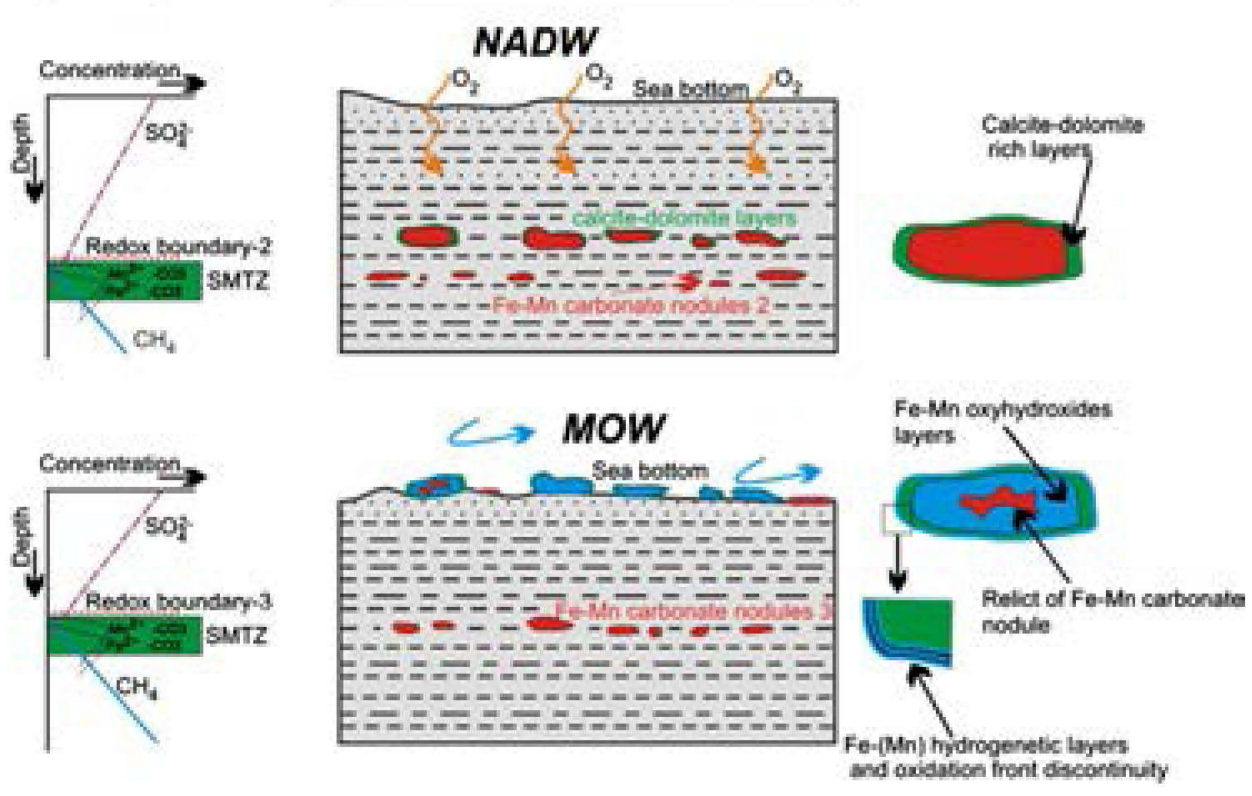

Fig. 11. Genetic model. Relationships between sulphate, methane, $\mathrm{Fe}^{2+}$ and $\mathrm{Mn}^{2+}$ concentration gradients in the pore waters. We also present the location of the redox boundaries and the sulphate-methane transition zone. The nodule may grow below the redox boundary within the sediments, forming an original concretion composed essentially of Fe-Mn carbonates. The erosive action of the MOW during the glacial periods produces the exhumation of Fe-Mn carbonate nodules that are replaced by Fe-Mn oxides through the action of the oxidising sea-bottom water. In eroding areas, the oldest nodules will be concentrated as an erosional lag on the seafloor, while the newest ones will form at depth. The NADW action promotes the oxygenation of pore waters in the Heinrich events, giving rise to precipitation of $\mathrm{Ca}$-rich layers. Alternatively, the NADW could promote deposition of sediments and burial of nodules at a depth level within the sedimentary column, favouring calcite-dolomite precipitation.

However, if the $\mathrm{pH}$ value is slightly acid, as may occur because of oxidation of framboidal pyrite from the nodules or surrounding sediments, then the Fe oxidation is favoured by microorganisms and ironoxidising bacteria are in chemical competition with chemical oxidation (reaction (9)). Pyrite oxidation results in goethite precipitation, as is observed in the nodules. This process could be supported by bacteria, as indicated above, according to the following reactions (Fortin et al., 1997):

$\mathrm{FeS}_{2}+7 / 2 \mathrm{O}_{2}+\mathrm{H}_{2} \mathrm{O} \rightarrow \mathrm{Fe}^{2+}+2 \mathrm{H}^{+}+\mathrm{SO}_{4}^{2-}$

$\mathrm{FeS}_{2}+1 / 2 \mathrm{O}_{2}+2 \mathrm{H}^{+} \rightarrow 2 \mathrm{Fe}^{3+}+\mathrm{H}_{2} \mathrm{O}$

Fe-Mn carbonate oxidation on the sea bottom could be driven by bacteria and/or chemically:

$4 \mathrm{FeCO}_{3}+2 \mathrm{H}_{2} \mathrm{O}+\mathrm{O}_{2} \rightarrow 4 \mathrm{FeOOH}+4 \mathrm{CO}_{2}$

$2 \mathrm{MnCO}_{3}+\mathrm{O}_{2} \rightarrow 2 \mathrm{MnO}_{2}+2 \mathrm{CO}_{2}$

The oxidation process begins on the outer edges of the nodule and moves progressively into the sample. Similar textural features were observed in the nuclear $\mathrm{Fe}-\mathrm{Mn}$ carbonates and the Fe-Mn oxide layers surrounding the nuclei. In accordance with these petrographical characteristics, we can infer a similar genetic process for nuclei and layers in the ferromanganese nodules studied. However, the mineralogy in the structural parts of the nodules, nuclei and layers is completely different; they have very similar micro-textural features:
1) micro-sparitic rhomboidal crystal sections in Fe-Mn carbonates from the nuclei and $\mathrm{Fe}-\mathrm{Mn}$ oxides from the layers; and 2) framboidal textures in pyrite from the nuclei and also in goethite from the layers.

The petrographical and geochemical analysis of the outermost layers in the nodules reveals new evidence of the MOW influence (Figs. 8 and 10). These layers are porous and have thin-layered colloform textures. These features are also observed in Fe-Mn micro-hardgrounds in HDACs (Fig. 6.2d). We have interpreted them as thin ferromanganiferous deposits precipitated by hydrogenesis from the MOW. The chemical interactions that take place in the column water and at the surface of nodules and hard substrates are poorly known. It is possible that Fe and Mn form inorganic or organic colloidal complexes, as is proposed by several authors for marine ferromanganese encrustations (e.g. Hein et al., 1997; 2000; 2010; Koschinsky and Hein;, 2003). These colloids precipitate onto hard-rock substrates as oxyhydroxides and trace metal ions are adsorbed into the iron and manganese minerals. The slow growth rates (62 mm/Ma vs. $113 \mathrm{~mm} / \mathrm{Ma}$ in the diagenetic growth) observed on the uppermost layers of ferromanganese nodules and in encrustations must be related to the events of erosion and precipitation of oxides from the seawater (hydrogenesis). These growth rates are various orders of magnitude higher than those frequently found in hydrogenous deep-sea nodules and crusts (average 1-6 mm/Ma) (Hein et al., 2000), probably because of the proximity of the CCC to continental areas. The outer layers of the nodules are characterised by their $\mathrm{Mn}$ depletion and high Fe enrichment in comparison with the average of the nodules. The low dissolved oxygen values in the MOW water (Cabeçadas et al., 2002) could have contributed, together with the 
intense undercurrent, to the depletion of Mn from the outer layers in the exhumed nodules (González et al., 2010). The different thermodynamic properties of solubility and therefore mobility of $\mathrm{Fe}^{2+}$ and $\mathrm{Mn}^{2+}$ during the erosive action of the MOW control the segregation of Mn. Some C-enriched filamentous textures observed in poorly crystalline Mn-oxides (birnessite-jianshuiite) from porous zones of the nodules (Fig. 6.1c) could be related to microbial-induced $\mathrm{Mn}^{2+}$ oxidation (fungal oxidation). Fungi have been reported as $\mathrm{Mn}^{2+}$ oxidising agents in marine waters and sediments, giving rise to poorly crystalline birnessite (Tebo et al., 1997).

The low ${ }^{87} \mathrm{Sr} /{ }^{86} \mathrm{Sr}$ isotopic values $(0.70724 \pm 0.00075 ; 0.70693 \pm$ 0.00081 ) of the outer edges of the nodules are spatially related to an oxidation front generated after nodule exhumation (Fig. 8a and b). The areas of the nodules affected by this oxidation front discontinuity could have undergone isotopic exchange with the seawater. We have interpreted these values as the imprint of the strontium isotopic values of the MOW at the edges of the nodules when the samples were exhumed. These non-radiogenic ${ }^{87} \mathrm{Sr} /{ }^{86} \mathrm{Sr}$ ratios are below the mean seawater isotope composition at the time span of nodule exhumation (0.70915-0.79020 during the late Pleistocene; McArthur et al., 2001). They could be attributed to a Levantine Intermediate Water-derived component in the MOW, mainly generated by the Nile River contribution, with an $\mathrm{Sr}$ isotopic composition of 0.706 (Brass, 1976; Albarède and Michard, 1987; Palmer and Edmond, 1992).

\subsection{Analogous ferromanganiferous deposits on continental margins}

In the next section, we discuss how the genetic and evolutionary model proposed above could be extrapolated to other ferromanganese deposits in the world that have developed in environments affected by contouritic and hydrocarbon-rich fluid venting processes. In addition, we suggest how these genetic conditions can be explored from marine ferromanganese mineral deposits in the geological record.

Numerous authors describe ferromanganese deposits associated with CDS in relation to their typology (nodules, micronodules, laminations and crusts) or their geological and oceanographic context (e.g. Massé et al., 1994; Faugères et al., 2002a; 2002b; Sivkov et al., 2002; Stow et al., 2002b; Tucholke, 2002). However, with respect to the petrography, mineralogy and geochemistry of ferromanganese deposits linked to CDS, there are few reported references (e.g. Summerhayes and Willis, 1975; Hartmann et al., 1989; Kasten et al., 1998; Mangini et al., 2001; Giresse, 2008). These issues, and consequently genetic models, have received little attention, and are often dealt with secondarily in sedimentological and/or palaeoceanographic studies. Contourite currents and their deposits are related to continental margins in all the ocean basins. These CDS are often coincident with areas affected by deep-seated fluid venting (mud volcanism and mud diapirism), as occurs in the Gulf of Cadiz, the Alboran Sea, the Gulf of Mexico, the Argentina Atlantic margin, the Brazil Basin, the South China Sea and others (e.g. Ercilla et al., 2002; Somoza et al., 2003; Chen et al., 2005; Chen et al., 2006; Hernández-Molina et al., 2006; 2010). In addition, on these margins the low sea-level stages should promote the washing of Fe from the continental shelves towards the deeper areas with Fe-oxyhydroxide-enriched sediments from highly weathered continental and shelf regions. The genetic model proposed in this paper could be extended to explain other ferromanganese deposits where analogous features meet: 1) continental margins above the carbonate compensation depth affected by contourite processes; 2) hydrocarbon-rich fluid venting seepage structures; and 3) supply of sufficient Fe and $\mathrm{Mn}$ to the pore-water sediments. Therefore, this genetic process and its textural, mineralogical and geochemical features could be seen today in other locations, and could help to explain the origin of other ferromanganese nodules from moments in the litho-stratigraphic record in which these circumstances also coincided. Partially oxidised siderite nodules associated with hydrocarbon-rich fluid venting systems and contourites have recently been discovered on the continental slopes of the South
China Sea and the western Moroccan margin (Chen et al., 2006; González et al., 2012). They are very similar to the ones studied in this paper and we can infer an analogous genetic-evolutionary model. Authigenic siderite nodules associated with gas hydrate decomposition and seepage structures have been discovered in boreholes 20 to $180 \mathrm{~m}$ below sea bottom in the Blake Ridge contourite deposit (northwest Atlantic) (Paull and Matsumoto, 2000). They may be growing according the diagenetic model proposed and could be exhumed in contouritic channels affected by bottom currents, as occurs in the Gulf of Cadiz. On other continental margins, such as the Argentina Atlantic margin, at present we do not have verification of similar ferromanganese deposits, but the strong seismic evidence of gas hydrates and free gas and of upward migration of gas and fluids discovered within the giant drifts (Hernández-Molina et al., 2010) supplies potential sites for nodule formation according to the model proposed in this work. Moreover, the formation of $\mathrm{Fe}-\mathrm{Mn}$ carbonate concretions would be possible in deepsea sediments below the carbonate compensation depth in special conditions such as in active gas hydrate systems. Indicators of this have been detected in the Peru Trench (Dicus et al., 2004) and could be present in other areas with a potential presence of gas hydrates (e.g. the Argentina or Uruguay margins). Continental margins, especially those near estuaries and deltas of large rivers (e.g. the Amazon Shelf), may be potential areas for supply of abundant iron and organic matter to the sea bottom sediments, promoting diagenetic growth of nodules according the model proposed.

Intense sediment reworking by sea bottom currents gave rise to the exhumation and oxidation of sulphides and carbonates by contact with oxygenated sea-bottom waters, as has been observed in the outer parts of siderite nodules from the South China Sea (Chen et al., 2006), as in the model proposed above. In addition, hydrogenetic ferromanganese crusts or laminas must develop on exhumed diagenetic nodules or hard-rock substrates, as occurs in the Gulf of Cadiz. This phenomenon of hydrogenesis is frequently associated with erosive features in contourite systems. Some examples of this are the nodule fields in the Vema and Columbia Channels in the southwest Atlantic and the Kane Gap and the Cape Basin in the southeast Atlantic (e.g. Rogers, 1987; Hartmann et al., 1989; Faugères et al., 2002a; 2002b; Giresse, 2008).

Some ferromanganese nodules and encrustations defined in the geological record (e.g. ferromanganese deposits from the AlpineMediterranean Arc) are probably of the same type as those defined herein and were generated by comparable processes. Ferromanganese tubotomaculum described onshore in clays from the Betic-Rifean Belt (Numidian clays) shows several structural, mineralogical, geochemical and geological characteristics (Pautot et al., 1975; Hamoumi and Chafik, 2006) in common with the ferromanganese nodules studied, because we can propose a similar genetic process. The existence of other sites in the world where ferromanganese deposits correspond to comparable genetic models must be confirmed by further studies. The keys to understanding these processes must be the textural, mineralogical and geochemical data: textural features such as rhomboidal ghosts or residual $\mathrm{Fe}-\mathrm{Mn}$ carbonates and framboids indicating past presence of carbonates and sulphides; the presence of microbe-like textures and biomarkers characteristics of SRB or Archaea; and anomalous enrichments in iron vs. manganese, presence of thermogenic hydrocarbons, carbon isotopes, etc.

Finally we would like to stress the importance of studies on hydrocarbon-related ferromanganese nodules for energy resource exploration. We propose the use of these ferromanganese nodules as tools for reconstructing the fluid venting history in modern or ancient hydrocarbon seeps. The nodules acted as "traps" for fluids during their growth, remaining for a long time when the fluids responsible for the mineralisation had disappeared in the area. Therefore, they can be useful for seep detection. In addition, these nodules and their thermogenic hydrocarbons may be used as indicators to explore and define deep-seated reservoirs for oil and gas, providing important 
information on sub-seafloor fluid composition, migration patterns, geology and tectonic conditions.

\section{Conclusions}

In this paper we present a dataset based on a complete characterisation, including imaging, geophysical, petrographical, mineralogical, geochemical and isotopic data on Fe-Mn nodules and microhardgrounds discovered in the Cadiz Contourite Channel. This dataset has allowed us to propose a genetic and evolutionary model of such deposits that can be tested elsewhere. The combined methods used to characterise the ferromanganese nodules and therefore the palaeofluid sources provided discriminating signatures for obtaining a genetic-evolutionary model. On the basis of these analyses we can conclude that the formation and evolution of ferromanganese deposits studied in this work appears to stem from the combination of diagenetic and hydrogenetic processes linked to the evolution of the Cadiz Contourite Depositional System controlled by tectonic and climatic/oceanographic events.

We propose that the ferromanganese carbonate nodules in the subsurface of the sea-bottom had a primary diagenetic origin under reducing conditions close to the sediment-water interface. The growth of the nodules began when the pore waters were sulphatedepleted, highly alkaline and enriched in $\mathrm{Fe}^{2+}$ and $\mathrm{Mn}^{2+}$. Sideriterhodochrosite laminas were formed concentrically below the redox boundary within the sulphate-methane transition zone. The presence of thermogenic and also mature hydrocarbons, such as phenanthrene, within the nodules indicates that diagenetic processes are related to deep-seated hydrocarbon seeps, probably through microbialmediated anaerobic oxidation of hydrocarbons. $\mathrm{High}^{87} \mathrm{Sr} /{ }^{86} \mathrm{Sr}$ isotopic values observed in the inner parts of nodules could thus be related to the influence of radiogenic fluids, probably fuelled by deep-seated fluid venting across the fault systems in the diapirs below the Cadiz Contourite Channel. Gas hydrate dissociation could be responsible for the higher oxygen isotopic values found in the Fe-Mn carbonates. Massive dissociation of gas hydrates could have occurred in the Cadiz Contourite Channel as a result of the action of the MOW during glacial periods.

The hydrogenous processes on seabed sediment must be controlled by episodes of exhumation caused by the action of the bottom current of the MOW. The variability in the growth of hydrogenous nodules and micro-hardgrounds may be related to the interface between the oxygenated and cold NADW and the briny and warm MOW. This action was more intensive in the glacial periods, when the lower core of the MOW was the most active, increasing the erosive action of the undercurrent in the area, giving rise to the exhumation of nodules and carbonate chimneys and crusts, and promoting the surface precipitation of $\mathrm{Fe}-(\mathrm{Mn})$ oxides by hydrogenesis from the seawater. The low ${ }^{87} \mathrm{Sr} /{ }^{86} \mathrm{Sr}$ isotopic values observed in the outer parts of nodules have a spatial relation with an oxidation front generated after nodule exhumation, and the outermost layers have suffered hydrogenesis with isotopic exchange with the MOW. The growth rate determined by ${ }^{230} \mathrm{Th}$ excess ${ }^{232} \mathrm{Th}$ opens the possibility of investigating palaeoenvironmental changes over the last $70 \mathrm{ka} . \mathrm{Ca}-$ rich layers observed in the nodules could correspond to the precipitation of calcite during episodes of invasion of the NADW via the Cadiz Contourite Channel in Heinrich events.

The nodules from the Cadiz Contourite Channel have allowed us to create a genetic and evolutionary model that goes beyond a simple local case study and may be applicable to other depositional contexts. This type of ferromanganese deposit is clearly linked to hydrocarbonrich fluid venting structures on continental margins above the carbonate compensation depth affected by contourite processes. They could be present in other similar areas around the world and also in the stratigraphic record, and may be indicators for exploration for energy resources.

\section{Acknowledgements}

This investigation is supported by CONTOURIBER project (CTM2008-06399-C04/MAR) of the Spanish Interministerial Commission of Science and Technology (CICYT). The authors thank all the scientific and technical staff who participated in the oceanographic cruises of the TASYO project onboard R/V Cornide de Saavedra and R/V Hespérides for the data acquisition and for their expertise in collecting the samples, which were essential for the writing of this paper. We also thank the staff of the "Centro de Microscopía Electrónica y Citometría", "Universidad Complutense de Madrid" (UCM), "Centro de Astrobiología" (CSIC/INTA), "Laboratorio de Estratigrafía Biomolecular" (UPM), "Servicio General de Isótopos Estables" (USAL), "Leibniz-Institut für Meerreswissenschaften an der Universität Kiel" (IFM-GEOMAR) and the laboratories of the "Instituto Geológico y Minero de España" (IGME) for allowing us to use their facilities. The authors thank Aline Dia, Andrea Koschinsky, an anonymous reviewer and the Editor, Barbara Sherwood Lollar, for their critical comments and suggestions that significantly improved the manuscript.

\section{Appendix A. Supplementary data}

Supplementary data to this article can be found online at doi:10. 1016/j.chemgeo.2012.03.030.

\section{References}

Abouchami, W., Galer, S.J.G., Koschinsky, A., 1999. Pb and Nd isotopes in NE Atlantic Fe-Mn crusts: proxies for trace metal paleosources and paleocean circulation. Geochimica et Cosmochimica Acta 63, 1489-1505.

Al-Aasm, I., Taylor, B.E., South, B., 1990. Stable isotope analysis of multiple carbonate samples using selective acid extraction. Chemical Geology: Isotope Geoscience Section $80,119-125$

Albarède, F., Michard, A., 1987. Evidence for slowly changing ${ }^{87} \mathrm{Sr} /{ }^{86} \mathrm{Sr}$ in runoff from freshwater limestones of southern France. Chemical Geology 64, 55-65.

Ambar, I., Howe, M.R., 1979a. Observations of the Mediterranean Outflow I. Mixing in the Mediterranean Outflow. Deep Sea Research 26A, 535-554.

Ambar, I., Howe, M.R., 1979b. Observations of the Mediterranean Outflow II. The deep circulation in the vicinity of the Gulf of Cadiz. Deep Sea Research 26A, 555-568.

Baraza, J., Ercilla, G., 1996. Gas-charged sediments and large pockmark like features on the Gulf of Cadiz slope (SW Spain). Marine and Petroleum Geology 13 (2). 253-261

Baturin, G.N., 1988. The Geochemistry of Manganese and Manganese Nodules in the Ocean. D. Riedel Publ. Co. 342 pp.

Beal, E.J., House, C.H., Orphan, V.J., 2009. Manganese- and iron-dependent marine methane oxidation. Science $325,184-187$

Berner, R.A., 1971. Principles of Chemical Sedimentology. McGraw-Hill, New York. $240 \mathrm{pp}$.

Berner, R.A., 1980. Early Diagenesis: A Theoretical Approach. Princeton University Press, Princeton, New York. 241 pp.

Berner, R.A., 1981. A new geochemical classification of sedimentary environments. Journal of Sedimentary Petrology 51, 359-365.

Bitgel, D., Himmler, T., Freiwald, A., Peckmann, J., 2008. A new constraint on the antiquity of anaerobic oxidation of methane: Late Pennsylvanian seep limestones from southern Namibia. Geology 36, 543-546.

Blinova, V.N., Comas, M.C., Ivanov, M.K., Poludetkina, E.N., Matveeva, T.V., 2011. Active mud volcanism in the West Alboran Basin: geochemical evidence of hydrocarbon seepage. Marine and Petroleum Geology 28, 1483-1504.

Boetius, A., Ravenschlag. K., Schubert, C.J., Rickert, D., Widdel, F., Gieseke, A., Amann, R., Joergensen, B.B., Witte, U., Pfannkuch, O., 2000. A marine microbial consortium apparently mediating anaerobic oxidation of methane. Nature 407, 623-626.

Bogdanov, Yu.A., Gurvich, E.G., Bogdanova, O.Yu., Ivanov, G.V., Isaeva, A.B., Muravév, K.G., Gorshkov, A.I., Dubinina, G.I., 1995. Ferromanganese nodules of the Kara Sea. Oceanology 34 (5), 722-732.

Borowski, W.S., Paull, C.K., Ussler, W., 1999. Global and local variations of interstitial sulphate gradients in deep-water, continental margin sediments: sensitivity to underlying methane and gas hydrates. Marine Geology 159, 131-154.

Brass, G.W. 1976. The variation of the marine ${ }^{87} \mathrm{Sr}^{86} \mathrm{Sr}$ ratio during Phanerozoic time: interpretation using a flux model. Geochimica et Cosmochimica Acta 40, 721-730.

Bryden, H.L., Stommel, H.M., 1984. Limiting processes that determine basic features of the circulation in the Mediterranean Sea. Oceanologica Acta 7, 289-296.

Cabeçadas, G., Brogueira, M.]., Gonçalves, C., 2002. The chemistry of Mediterranean Outflow and its interactions with surrounding waters. Deep Sea Research Part II 49 , $4263-4270$

Cacho, I., Grimalt, J.O., Sierro, F.J., Shackleton, N., Canals, M., 2000. Evidence for enhanced Mediterranean thermohaline circulation during rapid climatic coolings. Earth and Planetary Science Letters 183, 417-429. 
Cangemi, M., Di Leonardo, R., Bellanca, A., Cundy, A.B., Neri, R., Angelone, M., 2010. Geochemistry and mineralogy of sediments and authigenic carbonates from the Malta Plateau, Strait of Sicily (Central Mediterranean): relationships with mud/ fluid release from a mud volcano. Chemical Geology 276, 294-308.

Chen, D.F., Huang, Y.Y., Yuan, X.L., Cathles, L.M., 2005. Seep carbonates and preserved methane oxidizing Archaea and sulfate reducing bacteria fossils suggest recent gas venting on the seafloor in the Northeastern South China Sea. Marine and Petroleum Geology 22, 613-621.

Chen, Z., Yan, W., Chen, M.H., Wang, S.H., Lu, J., Zhang, F., Xiang, R., Xiao, S.B., Yan, P., Gu, S.C., 2006. Discovery of seep carbonate nodules as new evidence for gas venting on the northern continental slope of South China Sea. Chinese Science Bulletin 51 (10), 1228-1237.

Chester, R., 2000. Marine Geochemistry. Blackwell, Oxford. 506 pp.

Claude, C., Suhr, G., Hofmann, A.W., Koschinsky, A., 2005. U-Th chronology and paleoceanographic record in Fe-Mn crusts from the NE Atlantic over the last 700 ka. Geochimica et Cosmochimica Acta 69, 4845-4854.

Claypool, G.E., Kaplan, I.R., 1974. The origin and distribution of methane in marine sediments. In: Kaplan, I.R. (Ed.), Natural Gases in Marine Sediments. Plenum Press, New York, pp. 99-139.

Coleman, M.L., Moore, M.P., 1978. Direct reduction of sulfates to sulfur dioxide for isotopic analysis. Analytical Chemistry 50 (11). 1594-1595.

Díaz-del-Río, V., Somoza, L., Matínez-Frías, J., Mata, M.P., Delgado, A., Hernández Molina, F.J., Lunar, R., Martín Rubí, J.A., Maestro, A., Fernădez Puga, M.C., León, R. Llave, E., Medialdea, T., Vazquez, J.T., 2003. Vast field of hydrocarbon-derived carbonate chimneys related to the accretionary wedge/olistostrome of the Gulf of Cadiz. Marine Geology 195, 177-200

Dicus, C.M., Snyder, G.T., Dickens, G.R., 2004. Formation of carbonate concretions in deep-sea sediment below the CCD and above an active gas hydrate system. AGU, Fall Meeting abstract \#OS21A-1196.

Ercilla, G., Baraza, J., Alonso, B., Estrada, F., Casas, D., Farrán, M., 2002. The Ceuta Drift Alboran Sea, southwestern Mediterranean. In: Stow, D.A.V., Purdsey, C.J., Howe, J.A Faugeres, J.-C., Viana, A.R. (Eds.), Deep Water Contourites Systems: Modern Drifts and Ancient Series, Seismic and Sedimentary Characteristics: Geol. Soc. London, Memoirs, 22, pp. 155-170.

Faugères, J-C., Gonthier, E., Stow, D.A.V., 1984. Contourite drift molded by deep Mediterranean outflow. Geology 12, 296-300.

Faugères, J.-C., Zaragosi, S., Mézerais, M.L., Massé, L., 2002a. The Vema contourite fan in the South Brazilian basin. In: Stow, D.A.V., Pudsey, C.J., Howe, J.A., Faugères, J.-C Viana, A.R. (Eds.), Deep-Water Contourite Systems: Modern Drifts and Ancient Series, Seismic and Sedimentary Characteristics: Geol. Soc. London Mem., vol. 22 pp. 209-222.

Faugères, J.-C., Lima, A.F., Massé, L., Zaragosi, S., 2002b. The Columbia channel-levee system: a fan drift in the southern Brazil Basin. In: Stow, D.A.V., Pudsey, C.J., Howe, J.A., Faugères, J-C., Viana, A.R. (Eds.), Deep-Water Contourite Systems: Modern Drifts and Ancient Series, Seismic and Sedimentary Characteristics: Geol. Soc London Mem., vol. 22, pp. 223-238.

Fernández-Puga, M.C., Váquez, J.T., Somoza, L.. Díaz delRío, V., Medialdea, T., Mata, M.P. León, R., 2007. Gas-related morphologies and diapirism in the Gulf of Cadiz. In García-Gil, S., Jucd, A. (Eds.), Contrib 8th Int Conf Gas in Marine Sediments, 5-10 September 2005. : Vigo. Geo-Mar. Lett., 27. 2/4, pp. 213-221.

Fietzke, J., Liebetrau, V., Eisenhauer, A., Dullo, Ch., 2005. Determination of uranium isotope ratios by multi-static MIC-ICP-MS: method and implementation for precise U- and Th-series isotope measurements. Journal of Analytical Atomic Spectrometry 20,395-401

Fietzke, J., Liebetrau, V., Günther, D., Gurs, K., Hametner, K., Zumholz, K., Hansteen, T.H Eisenhauer, A, 2008. An alternative data acquisition and evaluation strategy for improved isotope ratio precision using LA-MC-ICP-MS applied to stable and radiogenic strontium isotopes in carbonates. Journal of Analytical Atomic Spectrometry $23(7), 955-961$.

Fomina, L.S., Volkov, I.I., 1969. Rare earths in iron-manganese concretions of the Black Sea. Doklady Akademii Nauk SSSR 185, 158-161.

Fortin, D., Ferris, F.G., Beveridge, T.J., 1997. Surface-mediated mineral development by bacteria. In: Bandfield, J., Nealson, K.H. (Eds.), Geomicrobiology: interactions between microbes and minerals. Reviews in Mineralogy, vol. 35. Mineralogical Society of America, Washington, D.C, pp. 161-177.

Frankel, R.B., Bazylinski, DA., 2003. Biologically induced mineralization by bacteria. In: Dove PM. De Yodero, J. Weiner, S. (Eds.), Biomineralization. Reviews in Mineralogy and Geochemistry, vol. 54. Mineralogical Society of America, Washington, D.C, pp. 95-110.

García, M., Hernández-Molina, F.J., Llave, E., Stow, D.A.V., León, R., Fernández Puga, M.C., Diaz del Río, V., Somoza, L., 2009. Contourite erosive features caused by the Mediterranean Outflow Water in the Gulf of Cadiz: Quaternary tectonic and oceanographic implications. Marine Geology 257, 24-40.

Gardner, J.M., 2001. Mud volcanoes revealed and sampled on the Moroccan continental margin. Geophysical Research Letters 28 (2), 339-342.

Gardner, J.V., Kidd, R.B., 1987. Sedimentary processes on the Iberian continental margin viewed by long-range side-scan sonar and seismic data. Journal of Sedimentary Petrology 57 (3), 397-407

Giresse, P., 2008. Some aspects of diagenesis in contourites. In: Rebesco, M. Camerlenghi, A. (Eds.), Contourites. Developments in Sedimentology, vol. 60. Elsevier, pp. 203-221.

Glasby, G.P., Gwozoz, R., kunzendorf, H., Friedrich, G., Thijssen, T., 1987. The distribution of rare earth and minor elements in manganese nodules and sediments for the equator and SW Pacific. Lithos 20, 97-113.

González, F.J., Somoza, L., Lunar, R., Martínez-Frías, J., Martín Rubí, J.A., Torres, T., Ortiz J.E., Diaz-del-Río, V., 2007. Fe-Mn nodules associated with hydrocarbon seeps: new discovery in the Gulf of Cadiz. Episodes 30 (3), 187-196.
Gonzałlez, F.J. Fietzke, J. Somoza, L. Lunar, R, Martinez-Frias, J. 2008. Strontium isotope profiles across ferromanganese nodules from the Gulf of Cadiz (eastern central Atlantic): growth history records. Geochimica et Cosmochimica Acta 72 (no. 13), A319.

Gonzałlez, F.J., Somoza, L, Lunar, R., Martínez-Frias, J., Martín Rubí, J.A., Torres, T., Ortiz J.E., Díaz del Río, V., Pinheiro, L.M., Magalhães, V.H., 2009. Hydrocarbon-derived ferromanganese nodules in carbonate-mud mounds from the Gulf of Cadiz: mudbreccia sediments and clasts as nucleation sites. Marine Geology 261, 64-81.

González, F.J., Somoza, L., Lunar, R., Martínez-Frías, J., Martín Rubí, J.A., Torres, T., Ortiz J.E., Diaz-del-Río, V., 2010. Internal features, mineralogy and geochemistry of ferromanganese nodules from the Gulf of Cadiz: the role of the Mediterranean Outflow Water undercurrent. Journal of Marine System 80, 203-218.

González, F.J., Somoza, L., Medialdea, T., León, R., Torres, T., Ortiz, J.E., Martín-Rubí, J.A. 2012. Discovery of ferromanganese hydrocarbon-related nodules associated with the Meknes mud volcano (Western Moroccan margin). Geophysical Research Abstracts vol. 14 EGU2012-12306.

Grootes, P.M., Stuiver, M., 1997. Oxygen 18/16 variability in Greenland snow and ice with $10^{-3}$ to $10^{-5}$ year time resolution. Journal of Geophysical Research 102 26455-26470.

Grootes, P.M., Stuiver, M., White, I.W.C., Johnsen, S.J., Jouzel, J., 1993. Comparison of oxygen isotope records from the GISP2 and GRIP Greenland ice cores. Nature 366 552-554.

Hamoumi, N., Chafik, M., 2006. Tubotomaculum of NW Rift Belt: mode of genesis and geological setting. UNESCO IOC Workshop Report: Final Proc. Int. Conf. Geologica processes on Deep-Water European Margins, Moscow, Russia, 201, pp. 23-24.

Han, X., Jin, X., Yang, S., Fietzke, J., Eisenhauer, A., 2003. Rhythmic growth of Pacific ferromanganese nodules and their Milankovitch climatic origin. Earth and Planetary Science Letters 211, 143-157.

Hartmann, M., Segl, M., Mangini, A., Beer, J., Bonani, G., Suter, M., Wölfli, W., 1989. The manganese nodules of the Kane Gap (East Atlantic). Indicators of sedimentationerosion changes. Geologische Rundschau 78, 943-958.

Hein, J.R., Koski, R.A., 1987. Bacterially mediated diagenetic origin for chert-hosted manganese deposits in the Franciscan Complex, California Coast Ranges. Geology $15(8), 722-726$

Hein, J.R., Schulz, M.S., Kang, J.K., 1990. Insular and submarine ferromanganese mineralization of the Tonga-Lau region. Marine Mining 9, 305-354.

Hein, J.R., Koschinsky, A., Halbach, P., Manheim, F.T., Bau, M., Kang, J.-K., Lubick, N. 1997. Iron and manganese oxide mineralization in the Pacific. In: Nicholson, K. Hein, J.R., Buhn, B., Dasgupta, S. (Eds.), Manganese Mineralization: Geochemistry and Mineralogy of Terrestrial and Marine Deposits: Special Publication Geological Society of London, London, vol. 119, pp. 123-138.

Hein, J.R., Koschinsky, A., Bau, M., Manheim, F.T., Kang, J.-K., Roberts, L., 2000 Co-rich ferromanganese crusts in the Pacific. In: Cronan, D. S. (Ed) Handbook of Marine Mineral Deposits. CRC Marine Science Series. CRC Press, Boca Raton, Florida, pp. 239-279.

Hein, J.R., Conrad, T.A., Staudigel, H., 2010. Seamount mineral deposits, a source of raremetals for high technology industries. Oceanography 23, 144-149.

Hensen, C., Nuzzo, M. Hornibrook, E., Pinheiro, L.M., Bock, B., Magallhães, V.H. Brückmann, W., 2007. Sources of mud volcano fluids in the Gulf of Cadiz indications for hydrothermal imprint. Geochimica et Cosmochimica Acta 71 (5), $1232-1248$

Hernández-Molina, F.J., Llave, E., Somoza, L., Fernández-Puga, M.C, Maestro, A. León, R., Medialdea, T., Barnolas, A., Garcia, M., Díaz-del-Río, V., Fernảndez-Salas, L.M. Vázquez, J.T., Lobo, F.J., Alveirinho-Dias, J.A., Rodero, J., Gardner, J., 2003. Looking for clues to paleoceanographic imprints: a diagnosis of the Gulf of Cadiz contourite depositional systems. Geology $31(1), 19-22$.

Hernảndez-Molina, FJ. Llave, E. Stow, D A V Garcia M Somoza, L Vázcuez, JT, Lobo, F.J., Maestro, A., Díaz del Río, V., León, R., Medialdea, T., Gardner, J., 2006. The contourite depositional system of the Gulf of Cadiz: a sedimentary mode related to the bottom current activity of the Mediterranean Outflow Water and its interaction with the continental margin. Deep Sea Research Part II 53, $1420-1463$

Hernảndez-Molina, F.J., Paterlini, M., Somoza, L., Violante, R., Arecco, M.A., de Isasi, M. Rebesco, M., Uenzelmann-Neben, G., Neben, S., Marshall, P., 2010. Giant mounded drifts in the Argentine Continental Margin: origins, and global implications for the history of the thermohaline circulation. Marine and Petroleum Geology 27, $1508-1530$.

Hinrichs, K.-U., Boetius, A., 2002. The anaerobic oxidation of methane: new insights in microbial ecology and biogeochemistry. In: Wefer, G., Billett, D., Hebbeln, D. Jørgensen, B.B., Schlüter, M., van Weering, T.C.E. (Eds.), Ocean Margin Systems. Springer-Verlag, Berlin, pp. 457-477.

Hlawatsch, S., Garbe-Schönberg, C.D., Lechtenberg, F., Manceau, A., Tamura, N., Kulik, D.A. Kersten, M., 2002. Trace metal fluxes to ferromanganese nodules from the western Baltic Sea as a record for long-term environmental changes. Chemical Geology 182 697-709.

Hodell, D.A. Mead, G.A. Mueller, P.A., 1990. Variation in the strontium isotopic composition of seawater ( $8 \mathrm{Ma}$ to Present) implications for chemical weathering rates and dissolved fluxes to the oceans. Chemical Geology 80, 291-307.

ISA, International Seabed Authority, 2000. Regulation on prospecting and exploration for polymetallic nodules in the area (ISBA/6/A/18). Selected Decisions and Documents of the Sixth Session, pp. 31-68.

Kasten, S., Glasby, G.P., Schulz, H.D., Friedrich, G., Andreev, S.I., 1998. Rare earth elements in manganese nodules from the South Atlantic Ocean as indicators of oceanic bottom water flow. Marine Geology 146, 33-52

Kennett, J.P., 1982. Marine Geology. Prentice Hall, Englewood Cliffs, New Jersey. $813 \mathrm{pp}$. 
Kenyon, N.H., Belderson, R.H., 1973. Bed forms of the Mediterranean undercurrent observed with side-scan sonar. Sedimentary Geology 9, 77-99.

Kohn, M.J., Riciputi, L.R., Stakes, D., Orange, D.L., 1998. Sulphur isotope variability in biogenic pyrite: reflections of heterogeneous bacterial colonisation? American Mineralogist 83, 1454-1468.

Konshauser, K., 2007. Introduction to Geomicrobiology. Blackwell Publishing. 425 pp.

Koschinsky, A., Hein, J.R., 2003. Uptake of elements from seawater by ferromanganese crusts: solid-phase associations and seawater speciation. Marine Geology 198 . 331-351.

Koschinsky, A., Halbach, P., Hein, J.R., Mangini, A., 1996. Ferromanganese crusts as indicators for paleoceanographic events in the NE Atlantic. Geologische Rundschau $85,567-576$.

Kozlova, E., Ivanov, M., Blinova, V., 2007. The replacement of aragonite by authigenic carbonates (in the mud diapiric ridges, the Gulf of Cadiz). Geophysical Research Abstracts 9, 06912.

León, R., Somoza, L., Medialdea, T., Maestro, A., Díaz-del-Río, V., Fernández-Puga, M.C., 2006. Classification of sea-floor features associated with methane seeps along the Gulf of Câdiz continental margin. Deep Sea Research Part II 53, 1464-1481.

León, R., Somoza, L., Medialdea, T., González, F.J., Díaz-del-Río, V., Fernăndez-Puga, M.C., Maestro, A., Mata, M.P., 2007. Sea-floor features related to hydrocarbon seeps in deepwater carbonate-mud mounds of the Gulf of Cadiz: from mud flows to carbonate precipitates. Geo-Marine Letters 27, 237-247.

León, R., Somoza, L., Dabrio, C.J., Ercilla, G., Praeg, D., Díaz del Río, V., Gómez-Delgado, M., 2009. A predictive numerical model for potential mapping of the gas hydrate stability zone in the Gulf of Cadiz. Marine and Petroleum Geology 26, 1564-1579.

León, R., Somoza, L., Medialdea, T., Hernández-Molina, F.J., Vázquez, J.T., Díaz-del Río, V., González, F.J., 2010. Pockmarks, collapses and blind valleys in the Gulf of Cadiz. Geo-Marine Letters 30 (3-4), 231-247.

Leôn, R. Somoza, L. Medialdea, T. Vázquez, JT, Gonzảlez, FJ., Lôpez-González, N, Casas, D., Mata, M.P., Fernández-Puga, M.C., Giménez-Moreno, C.J., Díaz-del-Río, V., 2012. New discoveries of mud volcanoes on the Moroccan Atlantic continental margin (Gulf of Cádiz): morpho-structural characterization. Geo-Marine Letters. doi: $10.1007 / 500367-012-0275-1$.

Llave, E., Hernández-Molina, F.J., Somoza, L., Díaz-del-Río, V., Stow, D.A.V., Maestro, A., Alveirinho Dias, J.M., 2001. Seismic stacking pattern of the Faro-Albufeira contourite system (Gulf of Cádiz): a Quaternary record of paleoceanographic and tectonic influences. Marine Geophysical Research 22, 487-508.

Llave, E., Schönfeld, J., Hernăndez-Molina, F.J., Mulder, T., Somoza, L., Díaz-del-Río, V., Sánchez-Almazo, I., 2006. High-resolution stratigraphy of the Mediterranean Outflow contourite system in the Gulf of Cadiz during the Late Pleistocene: the impact of Heinrich events. Marine Geology 227, 241-262.

Llave, E., Hernảndez-Molina, F.J., Stow, D., Fernández-Puga, M.C., Garcia, M., Vảzquez, J.T., Maestro, A., Somoza, L., Díaz del Río, V., 2007. Reconstructions of the Mediterranean Outflow Water during the quatemary based on the study of changes in buried mounded drift stacking pattern in the Gulf of Cadiz. Marine Geophysical Research 28, $379-394$.

Loubere, P., 1987. Changes in mid-depth North Atlantic and Mediterranean circulation during the Late Pliocene: isotope and sedimentologic evidence. Marine Geology 77. $15-38$.

Lovley, D.R., 1993. Dissimilatory metal reduction. Annual Review of Microbiology 47, 263-290.

Madelain, F., 1970. Influence de la topographie du fond sur l'ecoulement méditerranéen entre le Detroit de Gibraltar et le Cap Saint-Vincent. Cahiers Oceanographiques $22,43-61$.

Magalhães, V.H., 2007. Authigenic carbonates and fluid escape structures in the Gulf of Cadiz. Ph.D. Thesis. Univ. Aveiro, 422 pp.

Magalhães, V.H., Pinheiro, I.M., Ivanov, M.K., Kozlova, E., Blinova, V., Kolganova, J., Vasconcelos, C., McKenzie, J.A., Bernasconi, S.M., Kopf, A., Díaz-del-Río, V., González, F.J., Somoza, L., 2012. Formation processes of methane-derived authigenic carbonates from the Gulf of Cadiz. Sedimentary Geology 243-244, $155-168$.

Malconado, A., Somoza, L., Pallarés, L., 1999. The Betic Orogen and the Iberian-African boundary in the Gulf of Cadiz: geological evolution (central North Atlantic). Marine Geology 155, 9-43.

Mangini, A., Jung, M., Laukenmann, S., 2001. What do we learn from peaks of uranium and of manganese in deep sea sediments? Marine Geology 177, 63-78.

Manheim, F.T., Lane-Bostwick, C.M., 1988. Cobalt in ferromanganese crusts as a monitor of hydrothermal discharge on the Pacific sea floor. Nature $335,59-62$

Martín-Puertas, C., Mata, M.P., Fernández-Puga, M.C., Díaz-del-Río, V., Vázquez, J.T., Somoza, L., 2007. A comparative mineralogical study of gas-related sediments of the Gulf of Cádiz. Geo-Marine Letters 27, 223-235.

Massé, L., 1993. Sédimentation océanique profonde au Quaternaire. Flux sédimentés et paléocirculations dans l'Atlantique Sud-Ouest: Bassin Sud-Brésilien et prisme d'accrêtion Sud-Batbade. Thesis, Univ. Bordeaux I: $339 \mathrm{pp}$.

Massé, L., Faugères, J.-C., Bernat, M., Pujos, A., Mezerais, M.L., 1994. A 600,000 year record of Antarctic Bottom water activity inferred from sediment textures and structures in a sediment core from the southern Brazilian Basin. Paleoceanography 9, 1017-1026.

Mazurenko, L.L., Soloviev, V.A., Gardner, J.M., Ivanov, M.K., 2003. Gas hydrates in the Ginsburg and Yurna mud volcano sediments (Moroccan Margin): results of chemical and isotopic studies of pore water. Marine Geology 195 (1-4), 201-210.

McArthur, J.M., Howarth, R.J., 2004. Sr-isotope stratigraphy: the Phanerozoic ${ }^{87} \mathrm{Sr} /{ }^{86} \mathrm{Sr}$ curve and explanatory notes. In: Gradstein, F.M., Ogg, J.G., Smith, A.G. (Eds.), A Geological Timescale. Cambridge University Press, Cambridge, pp. 96-105.

McArthur, J.M., Howarth, R.J., Bailey, T.R., 2001. Strontium isotope stratigraphy: LOWESS version 3: best fit to the marine Sr-isotope curve for 0-509 Ma and accompanying look-up table for deriving numerical age. Journal of Geology 109 , $155-170$

Medialdea, T., Vegas, R., Somoza, L., Vázquez, J.T., Maldonado, A., Díaz-del-Río, V., Maestro, A., Córdoba, D., Fernández Puga, M.C., 2004. Structure and evolution of the "Olistostrome" complex of the Gibraltar Arc in the Gulf of Cadiz (eastern central Atlantic): evidence from two long seismic cross-sections. Marine Geology $209(1-4), 173-198$

Medialdea, T., Somoza, L., Pinheiro, L.M., Fernândez-Puga, M.C., Vazquez, J.T., León, R., Ivanov, M., Magalhães, V., Díaz-del-Río, V., Vegas, R., 2009. Tectonics and mud volcano development in the Gulf of Cádiz. Marine Geology 209 (1), 173-198.

Meese, D.A., Alley, R.B., Fiacco, R.J., Germani, M.S., Gow, A.J., Grootes, P.M., Illing, M., Mayewski, P.A., Morrison, M.C., Ram, M., Taylor, K.C., Yang, Q., Zielinski, G.A., 1994 Preliminary depth-age scale of the GISP2 ice core. Special CRREL Report 94-1, US

Melières, F., 1974. Recherches sur la dynamique sédimentuire du Golfe de Cádiz (Espagne). Ph.D. Thesis, University of Paris A: $235 \mathrm{pp}$.

Merinero, R., Lunar, R., Martínez-Frías, J., Somoza, L., Díaz del Río, V., 2008. Iron minerals in hydrocarbon seeps related carbonates, Gulf of Cadiz (southwest Iberian Peninsula). Marine and Petroleum Geology 25, 706-713.

Mulder, T., Voisset, M., Lecroart, P., Le Drezen, E., Gonthier, E., Hanquiez, V., Faugères, J.-C., Habgood, E., Hernández-Molina, F.J., Estrada, F., Llave, E., Poirier, D., Gorini, C., Fuchey, Y., Volker, A., Freitas, P., Lobo Sánchez, F., Fernández, L.M., Morel, J., 2003. The Gulf of Cádiz: an unstable giant contouritic levee. Geo-Marine Letters 23 (1), 7-18.

Munsell Color Co, 1980. Munsell Soil Color Charts. Ed. Munsell Co. Inc., Baltimore, MD.

Nealson, K.H., Myers, C.R., 1992. Microbial reduction of manganese and iron: new approaches to carbon cycling. Applied and Environmental Microbiology 58-2, 439-443.

Nealson, K.H., Stahl, DA., 1997. Microorganisms and biogeochemical cycles: What can we learn from layered microbial communities? In: Bandfield, J., Nealson, K.H. (Eds.), Geomicrobiology: interactions between microbes and minerals. Reviews in Mineralogy, vol. 35. Mineralogical Society of America, Washington, D.C., pp. 5-34.

Nelson, C.H., Maldonado, A., 1999. The Cadiz Margin study off Spain: an introduction. Marine Geology 155, 3-8.

Nelson, C.H., Baraza, J., Maldonado, A., 1993. Mediterranean undercurrent sandy contourites, Gulf of Cádiz, Spain. Sedimentary Geology 82, 103-131.

Nelson, C.H., Baraza, J., Maldonado, A., Rodero, J., Escutia, C., Barber, J.H., 1999. Influence of the Atlantic inflow and Mediterranean Outflow currents on Late Quaternary sedimentary facies of the Gulf of Cádiz continental margin. Marine Geology 155, 99-129.

Nicholson, K., Hein, J.R., Buhn, B., Dasgupta, S. (Eds.), 1997. Manganese Mineralization: Geochemistry and Mineralogy of Terrestrial and Marine Deposits: Special Publication Geological Society of London, London, vol. $119.370 \mathrm{pp}$.

Niemann, H., Duarte, J., Hensen, C., Omoregie, E., Magalhaes, V.H., Elvert, M., Pinheiro, L.M. Kopf, A., Boetius, A., 2006. Microbial methane turnover at mud volcanoes of the Gulf of Cadiz. Geochimica et Cosmochimica Acta 70-21, 5336-5355.

O'Neill-Barringer, M., Price, J.M., 1999. A review of physical oceanography of the Mediterranean Outflow. Marine Geology $155(1-2), 63-82$

Ochoa, J., Bray, N.A., 1991. Water mass exchange in the Gulf of Cadiz. Deep Sea Research $38(1)$, S465-S503.

O'Nions, R.K., Frank, M., von Blanckenburg, F., Ling, H.-F., 1998. Secular variation of Nd and $\mathrm{Pb}$ isotopes in ferromanganese crusts from the Atlantic, Indian and Pacific Oceans. Earth and Planetary Science Letters 155, 15-28.

Palmer, M.R., Edmond, J.M., 1989. The strontium isotope budget of the modern ocean. Earth and Planetary Science Letters 92, 11-26.

Palmer, M.R., Edmond, J.M., 1992. Controls over the strontium isotope composition of river water. Geochimica et Cosmochimica Acta 56, 2099-2111.

Paull, C.K., Matsumoto, R., 2000. Leg 164 overview. In: Paull, C.K., Matsumoto, R., Wallace, P.J., Dillon, W.P. (Eds.), Proceedings of the Ocean Drilling Program: Scientific Results, vol. 164

Pautot, G., Truillet, R., Hoofert, M., 1975. Tubotomaculum' et nodules de manganèse. Comparaison d'objets énigmatiques fossiles avec des concretions marines et lacustres. Bulletin de la Societe Geologique de France 17 (1), 25-37.

Peckmann, J., Thiel, V., 2004. Carbon cycling at ancient methane seeps. Chemical Geology 205, 443-467

Peckmann, J., Reimer, A., Luth, U., Luth, C., Hansen, B.T., Heinicke, C., Hoefs, J., Reitner, J., 2001. Methane-derived carbonates and authigenic pyrite from the notthwestern Black Sea. Marine Geology 177, 129-150.

Piper, D.Z., 1974. Rare earth elements in the sedimentary cycle: a summary. Chemical Geology 14, 285-305.

Pinheiro, L.M., Ivanov, M.K., Sautkin, A., Akhmanov, G., Magalhaes, V.H., Volkonskaya, A Monteiro, J.H., Somoza, L., Gardner, J., Hamouni, N., Cunha, M.R., 2003. Mud volcanism in the Gulf of Cadiz: results from the TTR-10 cruise. Marine Geology 195, 131-151.

Platt, J.P., Anczkiewicz, R., Soto, J--I., Kelley, S.P., Thirlwall, M., 2006. Early Miocene continental subduction and rapid exhumation in the western Mediterranean. Geology $34(11), 981-984$

Puteanus, D., Halbach, P., 1988. Correlation of Co concentration and growth rate-a method for age determination of ferromanganese crusts. Chemical Geology 69, 73-85.

Rebesco, M., Camerlenghi, A., 2008. Contourites. : Developments in Sedimentology, 60. Elsevier. $688 \mathrm{pp}$

Reyss, J.L., Marchig, V., Ku, T.L., 1982. Rapid growth of a deep-sea manganese nodule. Nature 295, 401-403.

Robinson, B.W., Kusakabe, M., 1975. Quantitative separation of sulphur dioxide for 34S/ $32 \mathrm{~S}$ analyses from sulphides by combustion with cuprous oxide. Analytical Chemistry 47, 1179-1181.

Rogers, J., 1987. Seismic, bathymetric and photographic evidence of widespread erosion and a manganese-nodule pavement along the continental rise of the southeast Cape basin. Marine Geology 78, 57-76. 
Rona, P.A., 2008. The changing vision of marine minerals. Ore Geology Reviews 33 , 618-666.

Scholz, F., Hensen, C., Reitz, A., Romer, R.L., Liebetrau, V., Meixner, A., Weise, S.M Haeckel, M., 2009. Isotopic evidence $\left({ }^{87} \mathrm{Sr} /{ }^{86} \mathrm{Sr}, \delta^{7} \mathrm{Li}\right)$ for alteration of the oceanic crust at deep-rooted mud volcanoes in the Gulf of Cadiz, NE Atlantic Ocean. Geochimica et Cosmochimica Acta 73, 5444-5459.

Sevastýanov, V.F., Volkov, LI., 1967. Redistribution of chemical elements in the oxidized layers of the Black Sea sediments and the formation of iron-manganese nodules. Trudy Instituta Okeanologii 83, 135-152.

Sivkov, V., Gorbatskiy, V., Kuleshov, A., Zhurov, Y., 2002. Muddy contourites in the Baltic Sea: an example of a shallow-water contourite system. In: Stow, D.A.V. Pudsey, C.J., Howe, J.A., Faugères, J.-C., Viana, A.R. (Eds.), Deep-Water Contourite Systems: Modern Drifts and Ancient Series, Seismic and Sedimentary Characteristics: Geol. Soc. London Mem., vol. 22, pp. 121-136.

Somoza, L., Díaz-del-Río, V., León, R., Ivanov, M., Fernández-Puga, M.C., Gardner, J.M. Hernảndez-Molina, F.J., Pinheiro, L.M., Rodero, J., Lobato, A., Maestro, A., Vâzquez, J.T. Medialdea, T., Fernández-Salas, L.M., 2003. Seabed morphology and hydrocarbon seepage in the Gulf of Cadiz mud volcano area: acoustic imagery, multibeam and ultra-high resolution seismic data. Marine Geology 195, 153-176.

Stadnitskaia, A., Ivanov, M., Blinova, V., Kreulen, R., Van Weering, T.C.E., 2006. Molecular and carbon isotopic variability of hydrocarbon gases from mud volcanoes in the Gulf of Cadiz, NE Atlantic. Marine and Petroleum Geology 23, 281-296.

Stadnitskaia, A., Nadezhkin, D., Abbas, B., Blinova, V., Ivanov, M.K., Sinninghe Damsté J.S., 2008. Carbonate formation by anaerobic oxidation of methane: evidence from lipid biomarker and fossil $16 \mathrm{~s}$ rDNA. Geochimica et Cosmochimica Acta 72 1824-1836.

Stein, L.Y., La Duc, M.T., Grundl, T.J., Nealson, K.H., 2001. Bacterial and archaea populations associated with freshwater ferromanganese micronodules and sediments. Environmental Microbiology $3(1), 10-18$

Stow, D.A.V., Reading, H.G., Collinson, J.D., 1996. Deep sea. In: Reading, H.G. (Ed.) Sedimentary Environments: Processes, Facies and Stratigraphy. Blackwell Science, London, pp. 395-453.

Stow, D.A.V. Pudsey, CJ. Howe, J.A., Faugères, J-C, Viana, A.R. (Eds.), 2002a. DeepWater Contourite Systems: Modern Drifts and Ancient Series, Seismic and Sedimentary Characteristics: Geol Soc London Mem, vol. 22. 464 pp.

Stow, D.A.V., Faugères, J.-C., Howe, J.A., Pudsey, C.J., Viana, A.R., 2002b. Bottom currents contourites and deep-sea sediment drifts: current state-of-the-art. In: Stow, D.A.V Pudsey, C.J., Howe, J.A., Faugères, J.-C., Viana, A.R. (Eds.), Deep-Water Contourite Systems: Modern Drifts and Ancient Series, Seismic and Sedimentary Characteristics: Geol. Soc. London Mem., vol. 22, pp. 7-20.

Stumpf, R., Frank, M., Haley, B.A., Schönfeld, J., 2010. Late Quaternary variability of Mediterranean Outflow Water from radiogenic $\mathrm{Nd}$ and $\mathrm{Pb}$ isotopes. Quaternary Science Reviews 29, 2462-2472.

Summerhayes, C.P., Willis, J.P., 1975. Geochemistry of manganese deposits in relation to environments on the sea floor around southern Africa. Marine Geology 18 , $159-173$.

Taylor, S.R., McLennan, S.M., 1985. The Continental Crust: Its Composition and Evolution. Blackwell Scientific Publications, Inc, 667 Lytton Avenue, Palo Alto. 328 pp.

Tebo, B.M., Ghiorse, W.C., Van Waasbergen, L.G., Siering, P.L., Caspi, R., 1997. Bacterially mediated mineral formation: insights into manganese (II) oxidation from molecular genetic and biochemical studies. In: Banfield, J.F., Nealson, K.H. (Eds.), Geomicrobiology: interactions between microbes and minerals. : Reviews in Mineralogy, vol. 35 Mineralogical Society of America, Washington, D.C, pp. 226-266.

Tebo, B.M., Bargar, J.R., Clement, B., Dick, G., Murray, K.J., Parker, D., Verity, R., Webb, S 2004. Manganese biooxides: properties and mechanisms of formation. Annua Review of Earth and Planetary Sciences 32, 287-328.

Templer, S.P., Wehrmann, L.M., Zhang, Y., Vasconcelos, C., McKenzie, J., 2011. Microbia community composition and biogeochemical processes in cold-water-coral carbonate mounds in the Gulf of Cadiz, on the Moroccan margin. Marine Geology $282(1-2), 138-148$.

Tucholke, B.E., 2002. The Greater Antilles Outer Ridge: development of a dista sedimentary drift by deposition of fine-grained contourites. In: Stow, D.A.V Pudsey, C.J., Howe, J.A., Faugères, J.-C., Viana, A.R. (Eds.), Deep-Water Contourite Systems: Modem Drifts and Ancient Series, Seismic and Sedimentary Characteristics: Geol. Soc. London Mem., vol. 22, pp. 39-55.

Usui, A., Someya, M., 1997. Marine Mn deposits in NW Pacific. In: Nicholson, K., Hein, J.R. Buhn, B., Dasgupta, S. (Eds.), Manganese Mineralization: Geochemistry and Mineralogy of Terrestrial and Marine Deposits: Special Publication Geological Society of London, London, vol. 119, pp. 177-198.

Vegas, R., Medialdea, T., Muñoz, M., Díaz del Río, V., Somoza, L., 2003. Nature and tectonic setting of the Guadalquivir Bank (Gulf of Cadiz, SW Iberian Peninsula). Revista. Sociedad Geologica de España 17 (1-2), 49-60.

Veizer, J., Ala, D., Azmy, K., Bruckschen, P., Buhl, D., Bruhn, F., Carden, G., Diener, A. Ebneth, S., Godderis, Y., Jasper, T., Korte, C., Pawellek, F., Podlaha, O., Strauss, H. 1999. ${ }^{87} \mathrm{Sr}{ }^{86} \mathrm{Sr}, \delta^{13} \mathrm{C}$ and $\delta^{18} \mathrm{O}$ evolution of Phanerozoic seawater. Chemical Geology $161,59-88$.

Viana, A.R., Rebesco, M. (Eds.), 2007. Economic and Palaeoceanographic Significance of Contourite Deposits: Geol. Soc. London Spec. Publ., vol. 276. 350 pp.

Viana, A.R. Almeida Jr. W. Nunes, M.CV, Bulhöes, E.M. 2007. The economic importance of contourites. In: Viana, A.R., Rebesco, M. (Eds.), Economic and Palaeoceanographic Significance of Contourite Deposits: Geol. Soc. London Spec. Publ., vol. 276, pp. 1-23.

Voelker, A. Lebreito, S. Schönfeld, I., Cacho, I. Exlenkenser, H., Abrantes, F., 2006 Mediterranean Outflow strengthenings during Northern Hemisphere coolings: a salt sources for the glacial Atlantic? Earth and Planetary Science Letters 245, 39-55.

von Stackelberg, U., 2000. Manganese nodules of the Peru Basin. In: Cronan, D.S. (Ed.) Handbook of Marine Mineral Deposits. CRC Press, pp. 197-238.

Walters, L.J., Claypool, G.E., Choquette, Ph.W., 1972. Reaction rates and $\delta^{18} \mathrm{O}$ variation for the carbonate-phosphoric acid preparation method. Geochimica et Cosmochimica Acta 36, 129-140.

Webb, S.M., Tebo, B.M., Bargar, J.R., 2005. Structural characterization of biogenic Mn oxides produced in seawater by the marine Bacillus sp. strain SG-1. American Mineralogist 90, 1342-1357.

Zahn, R., Sarnthein, M., Erlenkeuser, H., 1987. Benthic isotope evidence for changes of the Mediterranean Outflow during the Late Quaternary. Paleoceanography 2, 543-559.

Zheng, G., Fu, B., Takahashi, Y., Kuno, A., Matsuo, M., Zhang, J., 2010. Chemica speciation of redox sensitive elements during hydrocarbon leaching in the Junggar Basin, Northwest China. Journal of Asian Earth Sciences 39 (6), 713-723. 